-ISSN: 2148-0494

dergÍabant (AİBÜ İlahiyat Fakültesi Dergisi), Güz 2020, Cilt:8, Sayı:2, 8:732-759

Geliş Tarihi: 21.06.2020

Kabul Tarihi: 30.11.2020

Araștırma Makalesi

Doi: https://doi.org/10.33931/abuifd.755980

\title{
Âşûrâ Orucunun Kökeni ve Fıkhi Hükmünün Tahkiki
}

\begin{abstract}
Akif Dursun*
Öz

Muharrem ayının onuncu günü için İslam kültüründe âşûrâ kelimesi kullanılmaktadır. Rasûlullah'ın daha Mekke'de iken âşûrâ günü oruç tuttuğu, Medine'ye hicret ettikten sonra ilk Muharrem ayında hem kendisinin tutup hem de Müslümanlara emrettiği bilinmektedir. Ramazan orucu farz olduktan sonra âşûrâ günü oruç tutmak teşvik edilmiş ancak tutup tutmamak kişilere bırakılmıştır. Medine'de yaşayan Yahudilerin de bu günde oruç tuttuğuna ve bu güne tazim ettiğine dair çok sayıda hadis rivayet edilmiştir. Bu durum bazı Müslümanlar arasında rahatsızlık oluşturmuş, durumu Rasûlullah'a aktarmışlar, o da dokuzuncu günü de oruç tutulmasını emretmiş ancak kendisi bunu uygulamadan vefat etmiştir. Bu rivayetlere istinaden mezheplerde Muharrem'in dokuz ve onunda iki gün oruç tutmak teşvik edilmiş; Hanefî uleması ise Yahudilere benzemek manası taşıyacağı için sadece Muharrem'in onunda oruç tutmayı tenzihen mekruh görmüştür. Yahudilerin o gün oruç tuttuğuna ve tazim ettiklerine dair rivayetlere bakarak müsteşriklerin çoğunluğu ve onları takip eden bazı Müslüman araştırmacılar âşûrâ orucunun Yahudilerden alınan bir oruç olduğunu iddia etmişlerdir. Bu makalede âşûrâ ile ilgili bu iki konu yani âşûrânın bir Yahudi orucu olup olmadığı ve sadece Muharrem'in onunda oruç tutmakta kerahet bulunup bulunmadığı, rivayetler ve takvim karşılaştırmaları yapılarak incelenmiştir.
\end{abstract}

Anahtar Kelimeler: Oruç, Âşûrâ, Takvim, Yahudi, Muharrem.

\section{Origins of Fasting During the Day of Ashoura and Its Verification in terms of Fiqh}

\begin{abstract}
The term "ashoura" is used in Islamic culture for the $10^{\text {th }}$ day of Muharram. It's known that Rasulullah fasted in Muharram when he was in Macca and he ordered Muslims to do so in first Muharram after the hejira of Madina. After fasting during Ramadan became fardh, Ashoura fasting has been reccomended but never been accepted as compulsory. There are number of hadith about the jews performing the same fast and blessing that day. That situtaion created discomfort among Muslims, thereupon Rasulullah ordered them to fast during the $9^{\text {th }}$ day either, yet he passed away without practising it. Referring to these riwayat, it's been encouraged to fast both in $9^{\text {th }}$ and $10^{\text {th }}$ day of Muharram; moreover Hanafis have accepted fasting during only the $10^{\text {th }}$
\end{abstract}


day of Muharram as makruh tanzihi since it could be meant to resemble the jews. Most of the orientalists and Muslims following them claimed that ashoura fasting takes its source from the jews by looking at their blessing and performance of it. In this article, two main topics are examined: if there is a karahat to fast only at the $10^{\text {th }}$ day of Muharram and whether the ashoura is a Jewish fast by comparing narratives and calendars.

Keywords: Fasting, Ashorua, Calendar, Jew, Muharram.

\section{Giriş}

Bilindiği üzere Hanefîler, İbn Abbas'tan (r.a.) nakledilen hadislere istinaden, Ehl-i kitaba özellikle de Yahudilere benzememek için âşûrâ orucunun sadece Muharrem'in onunda tutulmasını mekruh görmüşler; bu sebeple, dokuzu veya on biri ile birlikte tutulmasının uygun olduğu hükmünü vermişlerdir. Ayrıca bazı müsteşrikler ve onları takip eden bazı Müslüman araștırmacılar da âşûrâ orucunun Yahudilerden alınma olduğunu iddia etmişlerdir. Günümüzde Yahudilerin, kullandıkları takvim sebebiyle, Muharrem ayının onuna isabet eden bir oruçları bilinmemektedir. Rasûlullah (s.a.v.) döneminde Yahudilerin Muharrem'in onuna hürmeten tuttukları bir oruç var mıydı? Varsa bu hangi oruçlarına tekabül ediyordu? $\mathrm{Bu}$ soruların cevapları net değildir. Bu makalede temelde iki mesele açıklığa kavuşturulmaya çalışılacaktır: Birincisi, âşûrâ orucu Yahudilerden alınma bir oruç mudur? İkincisi, sadece Muharrem'in onunda oruç tutmak mekruh mudur?

Bu soruların cevabını bulabilmek için âşûrâ orucu hakkındaki hadisler, fıkhî hükümler, Yahudilerin âşûrâ orucuna benzer oruçları olup olmadığı, takvim açısından âşûrâ orucunun Yahudilerin hangi dinî gününe geldiği incelenecektir.

\section{1. Âşûrâ Nedir?}

Genel kabule göre âşûrâ kelimesi on sayısını ifade eden aşr kökünden gelmektedir. Ancak bazı dilciler âşûrâ'nın Arapların develeri su başına getirdikleri günü anlatan ışr (الْعَر) kelimesinden alındığını bunun da dokuzuncu günü ifade ettiğini söylemişlerdir. ${ }^{1}$

Âsım Efendi (ö. 1235/1819), âşûrâ Muharrem'in onuna, bir kavle göre de dokuzuna denir. Develerin sulanma gününden alındığı kabul edildiğinde de onuncu olur, demektedir. ${ }^{2}$

Araplar, deve sulandıktan sonra sekiz gün ara verilir dokuzuncu gün su verilirse buna ışr demektedirler. Devenin ilk sulandığı gün, sekiz gün ara ve sulandığı günle toplam süre on gün ettiği için böyle denildiği ifade edilmektedir. ${ }^{3}$ Ancak bu sulama işi dokuzuncu gün olduğu için bazıları âşûrânın Muharrem'in dokuzu olduğuna buradan delil getirmiştir.

1 Ebu Muhammed Ali b. Zekeriyya el-Munbecî, el-Lübab fi'l-cem ' beyne's-sünne ve'l-Kitâb, thk. Muhammed Fadl Abdülaziz (Dımeșk: Dâru'l-Kalem, 1994), 1/408.

Mütercim Âsım Efendi, Kâmus Tercümesi (İstanbul: Bahriye Matbaası, 1305), 2/538.

Âsım Efendi, Kâmus Tercümesi, 2/539. 
Arapçada "fâûlâ" vezninin bulunmadığını ileri sürerek âşûrânın İbrânîce'den geldiğini söyleyenler de vardır. Fakat âlimlerin çoğu bu görüşe katılmamakta, kelimenin Arapça asıllı olduğunu benimsemektedirler. ${ }^{4}$

Dil âlimi İbn Düreyd (ö. 321/933), âşûrâ ismi İslam'da verilmiştir, cahiliyede böyle bir gün bilinmezdi, demiş, ${ }^{5}$ Hattabî (ö. 388/998) de onu takip etmiştir. ${ }^{6}$ Ancak bu görüş ulemanın çoğu tarafından kabul görmemiştir. Hz. Âişe ve Abdullah b. Ömer hadisleri de bu görüşün doğru olmadığını göstermektedir.

Ünlü dilci Halîl b. Ahmed (ö. 175/791) ve Leys b. Muzaffer (ö. 187/803 [?]), âşûrâ Muharremin onuncu günüdür demişlerdir. ${ }^{7}$ Sahâbe ve tabiin âlimlerinin çoğunluğu bu görüşte ${ }^{8}$ olduğu gibi daha sonraki ulemânın genelinin kabulü de budur. ${ }^{9}$ Muharrem'in dokuzuna âşûrâ denmesi kabul görmemiştir.

Âşûrânın menşei hakkında kaynakların belirttiği görüşleri iki noktada toplamak mümkündür. 1- Âşûrâ, Hz. Mûsâ ve kavminin, Firavun'un zulmünden kurtulduğu ve Yahudilerin oruç tutmakla mükellef olduğu bir gündür. Daha çok müsteşriklerin benimsediği bu görüşe göre Müslümanların mübarek bir gün olarak kabul edip oruç tuttukları âşûrâ, Yahudi geleneğine dayanmaktadır. ${ }^{10}$ 2- Âşûrâ, Hz. Nûh'tan itibaren bütün Sâmî dinlerde mevcut olan ve Câhiliye Arapları arasında da Hz. İbrâhim'den beri önemli görülüp oruç tutulan bir gündür. Bu görüş, Hz. Âişe ile Abdullah b. Ömer'in rivayetlerine dayanır. ${ }^{11}$

\section{2. Âşûrâ Hakkındaki Hadisler}

Âşûrâ orucunu Rasûlullah'ın vefatına kadar tuttuğu ve tavsiye ettiği hakkında sahih hadisler gelmiştir. ${ }^{12}$ Bazı rivayetlerde, Ramazan orucunun farz kılınmasından

4 Yusuf Şevki Yavuz, "Âşûrâ", Türkiye Diyanet Vakfı İslâm Ansiklopedisi (Ankara: TDV Yayınları, 1991), 4/26.

5 Ebû Bekr Muhammed İbn Düreyd, Cemheretü'l-luġa, thk. Remzi Münir Ba lebekkî (Beyrut: Dâru'lİlim, 1987), 2/727.

6 Ebû Süleymân Hamd el-Hattâbî, Ișlâḥu ġalați'l-muḥaddișîn, thk. Hâtime ed-Dâmin (Beyrut: Müessesetü'r-Risâle, 1985), 44; Garîbü'l-ḥadị̂s, thk. Abdülkerim İbrahim el-Garbâvî (Dımeşk: Dâru'l-Fikr, 1982), 3/240.

7 Ebû Mansûr Muhammed b. Ahmed el-Ezherî, Tehzî́bü'l-luġa, thk. Muhammed Ivad (Beyrut: Dâru İhyâi't-Türâsi'l-Arabiyye, 2001), 1/261.

8 Bedrüddîn el-Aynî, 'Umdetü'l-ḳārîfí şerḥi Șahîhịi'l-Buhâhrî (Beyrut: Dâru İhyâi't-Türâsi'l-'Arabî, ts.), $11 / 117$.

9 Şihâbüddîn İbn Hacer el-Askalânî, Fetḥu'l-bârî bi-şerḥi Șahîhhi'l-Buḩârî (Beyrut: Dâru'l-Ma'rife 1379), 4/245.

Bu iddia için bk. A. J. Wensinck, "Âşûrâ", MEB İslam Ansiklopedisi (İstanbul: Milli Eğitim Basımevi, 1978), 1/710-711.

11 Yavuz, "Âșûrâ", 4/26.

12 Bu hususta Ümmü Seleme'den (r.anhâ) rivayet edilen hadis için bk. Ebû Dâvûd Süleymân b. elEş'as es-Sicistânî, Sünen, thk. Muhammed Muhyiddin Abdülhamid (Beyrut: el-Mektebetü'lAsriyye, ts.), "Savm", 61 (No. 2437); Ebû 'Abdirrahmân Ahmed en-Nesâî, Sünen (es-suğrâ), thk. Abdülfettah Ebû Gudde (Haleb: Mektebetü'l-Matbûati'l-İslâmiyye, 1986), "Sıyam”, 69, 81 (No. 2372, 2417); Ahmed b. Muhammed b. Hanbel, el-Müsned, thk. Şuayb Arnavud vd. (Beyrut: Müessesetü'r-Risâle, 1421/2001), 37/24 (No. 22334). Hz. Aişe'den (r.anhâ) rivayet edilen hadis için bk. Ebû 'Abdullâh İbn Mâce el-Kazvînî (v. 273/887), Sünenü İbn Mâce, thk. Muhammed Fuad 
sonra Rasûlullah'ın tavsiye etmediği veya oruç tutmadığı gibi bir ima varsa da bu husustaki sahih hadisler aksini göstermektedir.

Rasûlullah'a (s.a.v.) aşûra günü oruç tutmanın hükmü sorulduğunda, "geçen senenin günahlarına kefâret olur" buyurmuştur. ${ }^{13}$ Bu hadisin bir başka versiyonunda, "âşûrâ günü orucunun Allah katında geçmiş yılın günahına kefâret olmasını umarım" geçmektedir. ${ }^{14}$

İbn Abbas (r.a.), "Nebî (s.a.v.), âşûrâ günü hariç hiçbir günün orucunu diğer günden üstün bulduğu için araştırmazdı." demiş ${ }^{15}$; Ebû Hanife (v. 150/767) tarafından mürsel olarak Said b. Cübeyr'den (ö. 94/713 [?]): “Âşûrâ orucu bir yıllık oruca, arefe günü orucu iki yıllık oruca denktir."16 hadisi nakledilmiştir.

Âşûrâ hakkında çok sayıda hadis nakledilmiştir. Fazileti ve Rasûlullah dönemindeki hükmü üzerine olan hadisleri bir tarafa bırakırsak konumuzla alakalı hadisleri üç ana grupta sınıflayabiliriz: 1- Kökeni ile ilgili hadisler, 2- İslam'da başlangıcı ile ilgili hadisler, 3- Tutulacağı gün ile ilgili hadisler.

\subsection{Kökeni ile İlgili Hadisler}

Âşûrâ orucunun hangi sebeple tutulduğu, hangi olaya bağlı olduğuna dair rivayetlere baktığımızda, Hz. Mûsâ'nın Firavun'un zulmünden kurtulduğu gün, Nûh tufanının sona erdiği gün, ${ }^{17} \mathrm{~Hz}$. Âdem'in tevbe ettiği gün ${ }^{18}$ ve bir kavmin tövbesinin kabul edildiği gün ${ }^{19}$ olduğuna dair rivayetlerinin yanında herhangi bir olay olmaksızın peygamberlerin bu orucu tuttuğ $\mathrm{u}^{20}$ rivayeti de vardır. Bu rivayetlerden ilk ikisi daha fazla ön plana çıkmıştır.

Abdülbakî (b.y.: Dâru İhyâi Kütübü'l-Arabî, ts.), "Siyam”, 41 (No. 1733). Muaz b. Cebel'den rivayet edilen hadis için bk. Ebû Dâvud, "Ezan”, 28 (No. 507); Ahmed b. Hanbel, el-Müsned, 36/436-438 (No. 22124). Nasîruddin Elbânî, bu hadislerin hepsine sahih demiștir. Ebu'l-Huseyn Müslim b. el-Haccâc, el-Câmi'u'ș-șahîh, thk. Muhammed Fuâd Abdülbâkī (Beyrut Dâru İhyâi't-Türâsi'l-Arabî, ts.), "Siyam”, 197 (No. 1162).

Müslim, "Sıyam”, 196 (No. 1162); Ebû Dâvud, "Savm”, 54 (No. 2425); İbn Mâce, "Sıyam”, 41 (No. 1738). Elbânî, sahih demiştir.

Muhammed b. İsmail el-Buhârî, el-Câmi'u'ș-șahîḥ, thk. Muhammed Züheyr b. Nâsır (b.y.: Dâru Tavki'n-Necât, 1422/2001), "Savm", 68 (No. 2006); Müslim, "Sıyam”, 131 (No. 1132); Nesâî, "Siyam”, 69 (No. 2370); Ahmed b. Hanbel, el-Müsned, 3/411 (No. 1938). Ebû Yûsuf Ya'kūb b. İbrâhîm, Kitâbü'l-Âsâr, thk. Ebu'l-Vefâ (Beyrut: Dâru'l-Kütübü'l-'İlmiyye, ts.), 177 (No. 804).

Abdürrezzâk b. Hemmâm es-San'ânî, el-Mușannef, thk. Habîburrahman el-A'zemî (Hind: elMeclisü'l-İlmî, 1403), 4/290 (No. 7849).

Abdürrezzâk, el-Mușannef, 4/291 (No. 7852).

Ebü'l-Hasen Alî b. el-Ca'd, el-Müsned, thk. Âmir Ahmed Haydar (Beyrut: Müessese Nâdir, 1990), 326 (No. 2526). Esved b. Yezîd (ö. 75/694), Ubeyd b. Umeyr’e âşûrâ orucunu sorduğunda o şöyle cevap vermiştir: "Muhakkak Muharrem, Allah'ın ayıdır. İçinde de âşûrâ günü vardır. Bir kavim o ayda büyük bir günah işledi de âşûrâ günü tevbe etti. Bu sebepten bu güne tevbe günü dendi. Sakın o günü oruçsuz geçirme!"

Ebû Bekr Abdullāh İbn Ebî Şeybe, el-Mușannef, thk. Kemal Yusuf el-Hût (Riyad: Mektebetü'r-Rüșd, 1409), 2/311 (No. 9355). Elbânî zaylf bulmuştur. bk. Daî́fu Câmi'i's-Saġîr (b.y.: el-Mektebü’lİslâmî, ts.), 513. 
Âşûrânın, Hz. Mûsâ ve İsrâiloğulları'nın Firavun'un zulmünden kurtulduğu gün olduğu ile ilgili rivayetlerin tamamına yakını İbn Abbas (r.a.) kanalıyla aktarılmıştır. Hadis şöyledir:

Rasûlullah (s.a.v.) Medine'ye geldiğinde Yahudilerin âşûrâ günü oruç tuttuklarını gördü. Rasûlullah (s.a.v.) onlara, "bu oruç tuttuğunuz gün nedir?" diye sordu. Onlar, "bu büyük bir gündür. Allah, Mûsâ ve kavmini bu günde kurtarmış, Firavun ve kavmini bu günde suda boğmuştur. Mûsâ da şükür için bugün oruç tutmuştur" dediler. Bunun üzerine Rasûlullah (s.a.v.), "Biz, Mûsâ hakkında daha fazla hak sahibi ve Mûsâ'ya sizden daha yakınız" buyurdu ve o gün hem kendisi oruç tuttu hem de oruç tutulmasını emretti. ${ }^{21}$

İbn Abbas (r.a.) haricinde bu minvalde tek rivayet Ebû Hüreyre'den (r.a.) aktarılmıştır. Buna göre, Nebî (s.a.v.), âşûrâ günü oruç tutan Yahudilerden bir gruba rastladı da onlara "bu orucu neden tutuyorsunuz?" diye sordu. Onlar, "bu gün Allah Mûsâ ve İsrâiloğulları'nı boğulmaktan kurtardı da Firavun'u suda boğdu. Bugün aynı zamanda Nûh'un gemisinin Cûdî dağına oturduğu gündür. Bu sebeple Nûh ve Mûsâ Allah'a şükür için bugün oruç tutmuşlardır" dediler. Nebî (s.a.v.), "ben Mûsâ'ya ve bugünün orucuna sizden daha fazla hak sahibiyim" buyurdu da ashabına oruç tutmalarını emretti. ${ }^{22}$ Ancak bu rivayet zayıf bulunmuştur.

Bu hususta İbn Hacer el-Askalânî (ö. 852/1449) İkrime b. el-Berberî’den (ö. 105/723), “Kureyş'in cahiliyede büyük bir günah işlediğini, bu günahı göğüslerinde çok büyüttüklerini, onlara aşura günü oruç tutarlarsa bu günahlarına kefâret olacağını söylenildiğini, onların da öyle yaptığını"23 aktarmıştır ki, muhtemelen İkrime, tövbesi kabul edilen kavmin Kureyş olduğu kanaatindedir. Kâbe'nin Câhiliye döneminde âşûrâ günü giydirildiği, Muâviye zamanında âşûrâ günü ipekten örtü atıldığı, bu geleneği Yezid b. Muaviye ve Abdullah b. Zübeyr'in devam ettirdiği nakledilmiştir. ${ }^{24}$

Bunun haricinde Hz. Îsâ b. Meryem'in o gün doğduğu, ${ }^{25} \mathrm{~Hz}$. Yûnus'un o gün balığın karnından kurtulduğu Hz. Yûsuf'un o gün kuyudan çıktığı, Hz. Yûnus'un kavminin o gün tevbe ettiği de aktarılmıștır, ${ }^{26}$ ancak güvenilir kaynaklarda bu

Buhârî, "Savm”, 68 (No. 2004), “Ehâdîsü'l-Enbiyâ", 26 (No. 3397), “Menâkibü'l-Ensar", 51 (No. 3943); “Tefsir", 158 ve 258 (No. 4680, 4737); Müslim, "Siyam”, 127, 128 (No. 1130); Ebû Dâvud, "Savm", 64 (No. 2444); Ahmed b. Hanbel, el-Müsned, 4/393, 5/36, 223, 250 (No. 2644, 2831, 3112, 3164); İbn Mâce, "Slyam", 41 (No. 1734). Ahmed b. Hanbel, el-Müsned, 14/335 (No. 8717). Tahkik edenler bu hadisin isnadının zaylf olduğunu, bu rivayette Ahmed b. Hanbel'in tek kaldığını kaydetmişlerdir. bk. aynı yer. İbn Hacer el-Askalânî, Fethu'l-bârî, 4/246 Ebü'l-Velîd Muhammed el-Ezrakī, Ahbâru Mekke, thk. Rüşdi es-Sâlih (Beyrut: Dâru Endülüs, ts.), 1/252-254.

Müstedrek'te İsa b. Meryem'in âşûrâ günü doğduğu nakledilmiş, ancak Zührî bu hadisin senedine çok kötü (vâhi) demiştir. bk. Muhammed el-Hâkim en-Nîsâbûrî, el-Müstedrek ale'ṣ-Ṣahîhhayn, thk. Mustafa Abdülkadir 'Ata' (Beyrut: Dâru'l-Kütübü'l-'Ilmiyye, 1990) 2/648 (No. 4155).

Abdullāh b. Ebî Zeyd el-Kayrevânî, en-Nevâdir ve'z-ziyâdât 'alâ mâ fi'l-Müdevvene ve ġayrihâ mine'l-ümmehât min mesâ'ili Mâlik ve așhâbih, thk. Muhammed Abdülaziz ed-Debbağ vd. (Beyrut: 
rivayetler bulunmamaktadır. Belki Ubeyd b. Umeyr'den aktarılan rivayette kastedilen kavim Hz. Yûnus'un kavmidir. Ancak bir açıklık yoktur.

\section{2. İslam'da Başlangıcı ile İlgili Hadisler}

$\mathrm{Bu}$ konuyla ilgili hadisler de iki ana gruba ayrılmaktadır. Birincisi Kureyşlilerin bu orucu tuttuğu, Rasûlullah'ın da buna uyduğu, Medine'de ise emrettiğini ifade eden hadisler; ikincisi de Rasûlullah Medine'ye hicret ettikten sonra Yahudilerin oruç tutmasını görerek emrettiğini işaret eden hadislerdir.

İlk grup hadislerin iki ana râvîsi Hz. Âişe (r.anha) ve Abdullah b. Ömer'dir (r.a.). Çok sayıda hadis kaynağında yer alan bu rivayet şöyledir:

"Kureyşliler cahiliye döneminde âşûrâ günü oruç tutarlardı. Rasûlullah (s.a.v.) da o gün oruç tutardı. Medine'ye hicret edince de o gün oruç tuttu ve oruç tutulmasını da emretti. Ramazan farz kılınınca "dileyen âşûrâ orucu tutsun, dileyen tutmasın" buyurdu." 27

Rasûlullah'ın (s.a.v.) Medine'ye hicret ettikten sonra Yahudilerin oruç tutmasını görerek bu orucu emrettiğini işaret eden hadislerin temel râvîsi Abdullah b. Abbas'tır. Bu hadis âşûrânın kökeni ile ilgili bölümde verilmişti. Abdullah b. Abbas (r.a.) haricinde Abdullah b. Ömer ${ }^{28}$ ve Ebû Mûsâ el-Eş'arî'den ${ }^{29}$ de bu minvalde rivayetler gelmiştir. Bu rivayetlerde Yahudilerin bu günde bayram yaptıklarına dair bir açıklık yoktur.

Yahudilerin, âşûrâ günü hem oruç tutup hem de bayram yaptıklarına dair rivayetler de gelmiştir. Bununla ilgili iki hadis şu şekildedir:

"Âșûrâ günü Yahudilerin oruç tuttukları ve bayram kabul ettikleri bir gündü. Rasûlullah (s.a.v.), "siz o gün oruç tutun" buyurdu." ${ }^{30}$

"Hayber ehli âşûrâ günü oruç tutuyorlar ve bayram kabul ediyorlardı. Kadınları o gün süsleniyorlar, yeni ve güzel elbiseler giyiyorlardı. Rasûlullah (s.a.v.),

Dâru'l-Garbi'l-İslâmî, 1999), 2/81; Ebû Bekir Muhammed b. Abdullah b. Yunus es-Sıkıllî, el-Câmit li-mesấ'ili'l-Müdevvene, thk. Doktora Öğrencileri (b.y.: Dâru'l-Fikr, 1434/2013), 3/1231-32. 42/175 (No. 25294); Müslim, "Siyam", 113-114, 116, (No. 1125); Ebû 'Îsâ Muhammed b. 'Îsâ etTirmizî, el-Câmi'u'l-kebîr (Sünen-i Tirmizî) (Mısır: Mustafa Babi'l-Halebî, 1975), "Savm”, 49 (No. 753); Ebû Dâvûd, "Siyam", 64 (No. 2442); Mâlik b. Enes, el-Muvatța', thk. Muhammed Fuad Abdülbakî (Beyrût: Daru İhyâi't-Türâsi'l-Arabî, 1985), "Sıyam”, 33 (No. 1052). Ayrıca bk. Buhârî, "Savm”, 68 (No. 2002), "Menâkibü'l-Ensar", 25 (No. 3831), "Tefsir", 20 (No. 4504) (Buradaki rivayetlerde hadisin son tarafı "âşûrâ orucu terk edildi de dileyen oruç tuttu, dilemeyen tutmadı" şeklindedir). Buhârî, "Hac", 47 (No. 1592); Ahmed b. Hanbel, el-Müsned, 43/185 (No. 26068) (Bu rivayetlerde "0 gün Kâbe'nin örtüldüğü gündü." ziyadesi vardır). Ayrıca ufak tefek farklılıklarla, Müslim, "Sıyam", 117-121 (No. 1126); Ebû Dâvud, "Savm", 64 (No. 2443); Ahmed b. Hanbel, elMüsned, 9/174 (No. 5202), 10/385 (No. 6292); İbn Mâce, "Siyam", 41 (No. 1737). Abdürrezzâk, el-Mușannef, 4/290 (No. 7848).

Buhârî, "Menâkibü'l-Ensar", 51 (No. 3942).

Ahmed b. Hanbel, el-Müsned, 32/445 (No. 19669). 
"siz o gün oruç tutun" buyurdu." ${ }^{11}$ Bu rivayetler, "o günü bayram kabul etmeyin, ancak oruç tutun" manasına anlaşılmaktadır.

Bununla birlikte Ebû Mûsâ el-Eşârî̀den (r.a.) bu günde Yahudilerin oruç tutmadığını ifade eden hadisler de nakledilmiştir. Bunlardan bir tanesi şöyledir:

"Âşûrâ günü Yahudilerin tazim ettiği ve bayram kabul ettikleri bir gündü. Rasûlullah (s.a.v.), "siz o gün oruç tutun" buyurdu." ${ }^{32}$

Bu hadis, Yahudilerin âşûrâ günü oruç tutmadıklarını, bayram yaptıklarını göstermektedir ki, İbn Hibbân (ö. 354/965) da bu kanaattedir. ${ }^{33}$ Bunlarla ilgili değerlendirmelerimizi aşağıda yapacağız.

\section{3. Âşûrâ Orucunun Tutulacağı Günle İlgili Hadisler}

Âşûrâ orucunun Muharrem'in onunda tutulduğu bilinmektedir. Bununla birlikte Muharrem'in onu ile birlikte dokuzuncu gününde de oruç tutulması, hatta sadece dokuzuncu gün tutulması gerektiğine dair görüşler de nakledilmiştir. Muharrem'in dokuzu ile ilgili rivayetlerin temel râvîsi Abdullah b. Abbas'tır (r.a.). Yukarıda zikrettiğimiz âşûrânın kökü olan "ışr" kelimesi ile ilgili "devenin sulanması" görüşünü bir kenara bırakırsak, Muharrem'in dokuzunda oruç tutma ile ilgili iki sebep ifade edilmektedir: Birincisi, Yahudilere benzememe, ikincisi de Muharrem'in onunu kaçırma korkusudur.

Makalemizin ana konusunu teşkil eden bu hususla ilgili rivayetler şöyledir:

Abdullah b. Abbas (r.a.) anlatıyor: Rasûlullah (s.a.v.), âşûrâ günü oruç tutup tutulmasını da emredince; "Yâ Rasûlallah, bugün Yahudi ve Hristiyanların tazim ettiği bir gündür" dediler. Bunun üzerine Rasûlullah (s.a.v.), "o zaman inşallah önümüzdeki yıl dokuzuncu gün tutarı" buyurdu. Ancak bir sonraki yll gelmeden Rasûlullah (s.a.v.) vefat etti. Bir rivayette "önümüzdeki yıla kalırsam muhakkak dokuzuncu gün tutarım" buyurdu. $^{34}$

el-Hakem b. el-A'rec anlatiyor: Abdullah b. Abbas'a zemzemin yanında ridasına yaslanmış hâlde iken vardım ve ona, "bana âşûrâ orucundan haber verir misin?" dedim. 0 şöyle dedi. "Muharrem hilalini görünce hazırlan. Dokuzuncu güne varınca oruçlu ol!” Rasûlullah (s.a.v.) bu günde mi oruç tutardı? dedim. Evet, dedi. ${ }^{35}$

31 Müslim, "Siyam”, 130 (No. 1131).

32 Buhârî, "Savm”, 68 (No. 2005); Müslim, "Sıyam”, 129 (No. 1131); İbn Ebî Şeybe, el-Mușannef, 2/311 (No. 9353). Müessesetü'r-Risâle, 1413/1993), 8/391; ayrıca bk. Macid Ahmed Niyazi ed-Derviș, Âşûrâ fi'şșeria've't-tarîh (Trablus: Dâru'l-İlim ve'l-Ulemâ, 1436/2014), 27. Müsned, 4/16 (No. 2105). Elbânî, sahih demiştir.

35 Müslim, "Siyam", 132 (No. 1133); Ebû Dâvûd, "Siyam", 65 (No. 2446); Tirmizî, "Savm", 50 (No. 754); Ahmed b. Hanbel, el-Müsned, 4/39, 91, (No. 2135, 2214). Elbânî, sahih demiştir. 
Atâ b. Ebû Rebâh'ın (ö. 114/732), nakline göre İbn Abbas âşûrâ günü hakkında, "Yahudilere muhalefet ediniz, dokuz ve onuncu gün oruç tutunuz!" demiştir. $^{36}$

Tahâvî (ö. 321/933) bu hadisi, İbn Abbas'ın (r.a.), Rasûlullah'ın (s.a.v.) "şayet önümüzdeki yıl yaşarsam âşûrâ orucunu dokuzuncu gün tutacağım” ifadesini böyle yorumladığını söylemektedir. ${ }^{37}$

Bir başka rivayette ise İbn Abbas'ın (r.a.), âşûrâ günü hakkında, "Yahudilere muhalefet ediniz, öncesinde veya sonrasında bir gün oruç tutunuz" dediği aktarılmıştır. ${ }^{38}$

Şu'be, İbn Abbas'ın (r.a.) seferde de âşûrâ günü orucunu tuttuğunu ve kaçırmaktan korktuğu için iki gün peşpeşe oruç tuttuğunu aktarmıştır. ${ }^{39}$

İbn Abbas'ın âşûrâ orucunun, gecesi 10 Muharrem olduğu için 9 Muharrem'de tutulacağı görüşünde olduğu, Dahhâk'ın (ö. 105/723) da aynı görüşü aldığı nakledilmiştir. ${ }^{40}$

Hasan-ı Basrî (ö. 110/728), Muhammed b. Münkedir (ö. 131/748), Saîd b. Müseyyeb (ö. 94/713), İkrime, Süfyân b. Uyeyne (ö. 198/814) ve Yunus b. Ubeyd'in (ö. 139/756) ise 10 Muharrem'de tutulacağı görüşünde oldukları nakledilmiştir. ${ }^{41}$

37 Ebû Ca'fer Ahmed et-Tahâvî, Şerḥu Me'âni'l-âsârr, thk. Muhammed Zührî - Muhammed Seyyid Câdu'l-Hak (b.y.: Âlemü'l-Kütüb, 1994), 2/78 (No. 3302). İbnü'l-Cevzî̀ye (v. 597), göre Rasûlullah'ın "önümüzdeki yıla yetişirsek dokuzunda tutarız" ifadesi dört manaya gelebilir: 1Yahudilere muhalefet için onuncu gün yerine dokuzuncu gün oruç tutmayı istemiş olabilir. 2- Yine Yahudilere muhalefet için dokuz ve onuncu gün oruç tutmayı istemiş olabilir. 3- Tek başına bir gün oruç tutmayı hoş görmediği için ikinci bir gün katmak istemiş olabilir. 4- Âşûrâ dokuzuncu gündür. İbn Abbas'ın görüşü de budur. (Ebü'l-Ferec Cemâlüddîn İbnü'l-Cevzî, el-Kesş li-müsskili'șȘahîḥayn, thk. Ali Hüseyn el-Bevvâb (Riyad: Dâru'l-Vatan, ts.), 2/461). İbn Hacer el-Askalânî'ye (ö. 852/1449) göre ise Rasûlullah bu sözü ile âşûrâ orucunu ya Muharrem'in dokuzuna nakletme ya da bir gün eklemeyi kast etmiștir (Fetḩu'l-bârî, 4/246).

Ali b. el-Ca'd, el-Müsned, 349 (No. 2411); Ebû Bekr Ahmed el-Beyhakī, Şu'abü'l-îman, thk. Abdülalî Abdülhamid (Riyad: Mektebetü'r-Rüșd, 2003), 5/329 (No. 3509); Ahmed b. Hanbel, el-Müsned, 4/52 (No. 2154); Ebû Bekr Muhammed İbn Huzeyme, es-Sahîh, thk. Muhammed Mustafa elA'zamî (Beyrut: el-Mektebü'l-İslâmî, ts.), 3/290 (No. 2095). Bu ifade sadece Ahmed b. Hanbel'in rivayetinde Rasûlullah'a (s.a.v.) ref edilmiştir, ancak eseri tahkik edenler isnadının zayıf olduğunu, İbn Abbas'a ulaşan mevkuf rivayetin sahih olduğunu söylemişlerdir (bk. 4/52-53). Elbânî de İbn Huzeyme'nin rivayetine yaptığı talikte aynı kanaattedir. 


\section{Mezheplere Göre Âşûrâ Orucunun Fıkhî Hükmü}

Âşûrâ orucunun ilk başlarda farz olup olmadı̆̆ı hususunda mezhepler arasında ihtilaf vardır. Her iki görüşü de doğrulayacak hadisler olsa da farz olduğu görüşü daha kuvvetlidir.

Rasûlullah'ın (s.a.v.),1 Medine'ye geldikten sonraki ilk Muharrem ayının onunda sahâbeye oruç tutmayı emrettiğine dair çok sayıda hadis vardır.

Başta Seleme b. Ekva' ve Rübeyyi' bt. Muavviz olmak üzere Ensar'dan farklı sahâbîlerden ${ }^{42}$ Rasûlullah'ın (s.a.v.) Medine merkezi ve çevre mahalle ile köylere adamlar göndererek ${ }^{43}$, âşûrâ gününü oruçlu geçirmelerini istediği, âşûrâ günü sabahı: "Kim bir şeyler yemişse günün geri kalanında oruç tutsun. Kim de bir şey yememişse oruç tutsun. Çünkü bu gün âşûrâ günüdür!” diye ilan ettirdiği; ${ }^{44}$ bu emri yerine hakkıyla yerine getirmek isteyen bazı hanım sahâbîlerin çocuklara bile oruç tutturduğu, onları oyalamak için çeşitli yünden oyuncaklar yaptıkları; ${ }^{45} \mathrm{~Hz}$. Âişe (r.anha) ve Abdullah b. Ömer'den (r.a.) Rasûlullah'ın (s.a.v.) âşûrâ günü oruç tuttuğu ve oruç tutulmasını emrettiği, Ramazan orucu farz kılınınca insanları serbest bıraktığı nakledilmiştir. ${ }^{46}$

Âşûrâ günü oruç tutmanın ilk başlarda farz olduğu hususundaki en açık hadislerden biri şudur:

Câbir b. Semûre (r.a.), "Rasûlullah (s.a.v.) âşûrâ günü orucunu bize emreder, ona teşvik eder ve o gün oruçlu olmamız için bizden söz alırdı. Ramazan orucu farz kılınınca âşûrâ günü orucunu emretmediği gibi yasaklamadı da, o gün oruç için söz de almadı" demiştir. ${ }^{47}$

42 Rivayetler için bk. Ahmed b. Hanbel, el-Müsned, 25/325 (No. 15962); 27/273 (No. 16716); 45/612 (No. 27646); Abdürrezzâk, el-Mușannef, 4/286 (No. 7835; Ebû Bekr Abdullāh İbn Ebî Şeybe, el-Müsned, thk. Adil b. Yusuf - Ahmed b. Ferîd (Riyad: Dâru'l-Vatan, 1997), 2/116 (No. 611). Muhammed b. Sayfî̀nin anlatımına göre Rasûlullah (s.a.v.) âşûrâ günü onlara, "Sizden bugün bir şey yiyen var mı?" diye sormuş, onlar da "Bizden yiyen de var, yemeyen de var", diye cevap verince; "(bir şey) yemiş olan da (bir şey) yememiş olan da bu gününüzün kalan kısmını (oruçla) tamamlasın ve Arûz halkına haber gönderin de onlar da günün kalan kısmını (oruçla) tamamlasınlar" buyurmuştur. Müslim, "Sıyam”, 21, İbn Mâce, "Sıyam", 41 (No. 1735); Nesâî, "Sıyam”, 64 (No. 2320); Ahmed b. Hanbel, el-Müsned, 32/200 (No. 19541). Elbânî, sahih demiștir. Râvînin aktarımına göre Aruz halkı, Medine civarındaki arazi sahipleridir. Buhârî, "Savm”, 21, 68 (No. 1924, 2007); Müslim, "Siyam”, 135 (No. 1135); Nesâî, "Siyam”, 65 (No. 2321); Ahmed b. Hanbel, el-Müsned, 27/34, 40, 57 (No. 16508, 16512, 16526). Buhârî, "Savm", 46 (No. 1960); Müslim, "Siyam", 136-137 (No. 1136). Hanbel, el-Müsned, 43/185 (No. 26068. Benzeri bir rivayet için bk. Buhârî, "Savm”, 1 (No. 1892), 68 (No. 2000); Müslim, "Slyam”, 119 (No. 1126); Ahmed b. Hanbel, el-Müsned, 8/63 (No. 4483). 
Hanefiler ${ }^{48}$ ve Malikiler ${ }^{49}$ ilk başta âşûrâ orucunun farz olduğu, sonra ramazan ile bu farziyetin neshedildiği görüşündedirler. Hanefî ve Mâlikîlerin delilleri bu husustaki açık hadislerdir. Tahâvî âşûrâ orucu hakkındaki oruçları derleyerek, âşûrâ orucunun ilk başlarda farz olduğu görüşünün doğru olduğunu ifade etmiştir. ${ }^{50}$

Şâfiî ve Hanbelîlerde ise mezhepte ihtilaf olmasına rağmen geçerli görüş en baştan itibaren sünnet olduğu yönündedir. ${ }^{51}$ Şâfiîlerden ilk baştan farz olmadığ görüşünde olanlar temelde Muaviye hadisini ${ }^{52}$ delil almışlardır. Nevevî̀ye (ö. 676/1277) göre ilk başta kuvvetli sünnettir..$^{53}$

Şâfiî ulemasının tamamı âşûrâ orucunun ilk baştan nafile olduğu hususunda ittifak hâlinde değildir. İsim verilmeden bazı Şafîi âlimlerinin İmam Ebû Hanîfe'nin görüşüne katıldığı nakledilmiştir. ${ }^{54}$ Nevevî, İmam Şâfî̀'den (ö. 204/820) âşûrânın ilk başta farz olduğu ve olmadığı yönünde iki görüş nakledildiğini, ancak daha sahih olanı, Şâfiî âlimlerinin çoğunluğunun tercih ettiği görüşün ve İmam Şâfiî̀nin ifadesinin zahirinin, farz olmadığı yönünde olduğunu söylemektedir. ${ }^{55}$

Âşûrâ orucunun ilk başta vacip olup olmadığı hususunda Hanbelî mezhebinde ihtilaf olduğunu söyleyen İbn Kudâme (ö. 620/1223), Kadı (Ebû Yaclâ)'nın (ö. 458/1066) vacip olmadığı görüşünde, mezhebin kıyasının da bu yönde olduğunu ifade etmiştir. Bununla birlikte Ahmed b. Hanbel'den (ö. 241/855) vacip olduğu da

48 Cessas Ebû Bekir Ahmed b. 'Alî, Şerḥu Muhtașari'ț-Ṭaḥ̂̂î (Beyrût: Dâru'l-Beșâ'iri'l-İslâmiyye, 2010) 2/404; Ebü'l-Hüseyn Ahmed el-Kudûrî, et-Tecrîd (Kahire: Dâru's-Selam, 2006), 3/143839; Șemsü'l-eimme Muhammed es-Serahsî, el-Mebsût (Beyrut: Dâru'l-Ma'rife, ts.), 3/67; Alâüddîn Ebû Bekr el-Kâsânî, Bedâ’i'u'ș-șanâ'ic fí tertîbi'ş-şerâ'i ' (Beyrut: Dâru'l-Kütübü'l-'İlmiyye, 1986), 2/103.

Ebu'l-Velid Muhammed İbn Rüșd (el-Cedd), el-Beyân ve't-tahṣ̂il, thk. Muhammed Haccî ve arkadaşları (Beyrut: Dâru'l-Garbi'l-İslâmî, 1988), 17/324.

50 Ebû Ca'fer Ahmed et-Tahâvî, Şerḥu Müşkili'l-âsấr, thk. Şuayb el-Arnaut (Beyrut: Müessesetü Risâle, 1415), 6/36-48 (No. 2258-2277); Şerḥu Me âni'l-âsârr, 2/57 (No. 3193). Tahâvî'nin bu hususta naklettiği hadislerden birinde, Abdullah b. Mes`ud'un âşûrâ günü yanına Şakik b. Seleme'nin geldiği, Abdullah'ın (r.a.) taze hurma ikram ettiği ancak Şakik'in "bugün âşûrâ ve ben oruçluyum" diyerek ikramı reddettiği, bunun üzerine Abdullah'ın (r.a.), "biz Ramazan farz kılınmadan önce o gün oruç tutmakla emrolunmuştuk" dediği rivayet edilmiștir. (Tahâvî, Şerḥu Me âni'l-âsâr, 2/74 (No. 3276.)

51 Ebü'l-Hasen Alî el-Mâverdî, el-Hâvi'l-kebîr (Beyrut: Dâru'l-Kütübü'l-'ỉlmiyye, 1999), 3/401, 405;

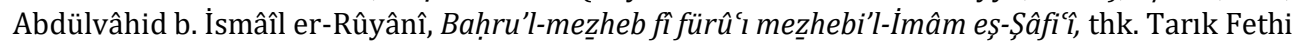
es-Seyyid (Beyrut: Dâru'l-Kütübü'l-'İlmiyye, 2009), 3/306; Muvaffakuddîn İbn Kudâme, el-Muǵnî (Kâhire: Mektebetü'l-Kâhire, 1968), 3/110.

52 Muaviye b. Ebî Süfyan, hacca geldiği yıl âşûrâ gününde Medine'de minberde şöyle demiştir: “Ey Medine ehli! Âlimleriniz nerede? Ben Rasûlullah'ın (s.a.v.) şöyle buyurduğunu işittim: “Bu âşûrâ günüdür. Allah bu günü sizin üzerinize farz kılmamıştır. Ben ise oruçluyum. Dileyen oruç tutsun, dileyen yesin!" (Buhârî, "Savm”, 68 (No. 2003); Ahmed b. Hanbel, Müsned, 28/81 (No. 16867) Ahmed b. Hanbel'de "insanlar oruç tuttu” ziyadesi vardır. Müslim, "Sıyam”, 126 (No. 1129); Nesâî, "Siyam", 65 (No. 2371); İmam Mâlik, "Sıyam", 34 (No. 1053); Muhammed b. İdrîs eş-Şâfi î, elMüsned (Beyrut: Dâru'l-Kütübü'l-'İlmiyye, 1400), 161.) Ebû Zekeriyyâ Yahyâ b. Şeref en-Nevevî, el-Mecmû́ șerḥu'l-Mühezzzeb (b.y.: Dâru'l-Fikr, ts.), 6/301. Yahyâ b. Ebu'l-Hayr el-İmrânî, el-Beyân fi mezhebi'l-İmam eş-Şâfi î, thk. Kâsım Muhammed Nuri (Cidde: Dâru'l-Minhâc, 2000), 3/551.

55 Nevevî, el-Mecmûc, 6/383. İmam Şâfiî’nin görüşü için bk. Muhammed b. İdrîs eş-Şâfi î, İhtilâfü'lhadîs (el-Ümm'ün sonunda) (Beyrut: Dâru'l-Ma'rife, 1990), 8/610. 
rivayet edilmiştir. Bu husustaki delil Hz. Âişe hadisidir. ${ }^{56}$ Âşûrâ orucunun baştan farz olduğu sonra farz hükmünün nesh edildiği hususundaki rivayet ve görüşleri İbn Teymiyye (ö. 728/1328) daha güçlü bulmuștur. ${ }^{57}$ İbn Teymiyye, Rasûlullah'ın (s.a.v.) nübüvvetten önce de bu orucu tuttuğunu, nübüvvetten sonra da bunu devam ettirdiğini, Medine'ye gelince Hz. Mûsâ'ya muvafakat ettiğini, sonra da Yahudilere benzemenin neshedildiğini söylemektedir. ${ }^{58}$ İbn Müflih (ö. 763/1362) de şeyhlerinin farz olduğu görüşünü tercih ettiğini, İbn Kudâme'nin de bu görüşe meylettiğini söylemiştir. ${ }^{59}$

Şâfiîlerin ve İbnü'l-Cevzî'nin (ö. 597/1201) Muaviye hadisini delil göstererek âşûrâ orucunun önceden de mendup olduğu, farz olmadığı görüşüne Hanefiler, Muaviye'nin var olan durumu söylediğini, zaten onun Mekke'nin fethi esnasında müslüman olup Medine'ye geldiğini, o zaman da âşûrâ orucunun farziyetinin neshedilmiş olduğunu söyleyerek cevap vermişlerdir. ${ }^{60}$

Ramazan orucu farz kılındıktan sonra âşûrâ orucunun hükmü hususuna gelince, Taberî (ö. 310/923), sahâbeden âşûrâ günü oruç tutmayı müstehap görenlerle mekruh görenleri yazmıştır. Buna göre oruç tutulmasını müstehap hatta gerekli gören sahâbîler şunlardır: Hz. Ali, Ebû Mûsâ el-Eşârî, Hz. Âişe, Abdurrahman b. Avf, Hz. Ömer, İbn Abbas, Ubeyd b. Umeyr, (Said b. Müseyyeb'in rivayetine nazaran) Hz. Ebû Bekir. ${ }^{61}$ Taberî̀ye göre Abdullah b. Mes'ud da müstehap görenlerdendir. ${ }^{62}$

Taberî, âşûrâ günü oruç tutmayı mekruh görenler başlığında sadece Abdullah b. Ömer'i ve onunla ilgili rivayetleri zikretmiştir. ${ }^{63}$ Ona göre Abdullah b. Ömer âşûrâ orucunu mekruh görmektedir. Bu görüşü İbn Müflih de tekrar etmiştir.64 Ancak Nafi'den nakledilen, İbn Ömer'in (r.a.), mukim iken âşûrâ günü oruç tuttuğuna dair rivayet, $^{65}$-eğer sıhhatli ise- bunu doğrulamamaktadır. Doğrusu müstehap görmemesi,

İbn Kudâme, el-Muġnî, 3/177-178; Ebü'l-Ferec Şemsüddîn İbn Kudâme, eș-Şerḥu'l-kebîr (Dâru'lKitâbi”l- b.y.: Arabî, ts.), 3/104-105.

Takıyyüddîn İbn Teymiyye, Kitâbu's- șlyam min şerhii'l-'Umde, thk. Zâid b. Ahmed (b.y.: Dâru'lEnsârî, 1996), 2/572-575.

İbn Teymiyye, Kitâbu's-șlyam, 2/579.

Şemsüddîn Muhammed İbn Müflih, Kitâbü'l-fürû́, thk. Abdullah b. Abdülmuhsin et-Türkî (Beyrut: Müessesetü'r-Risâle, 2003), 5/92.

Bedreddîn el-Aynî, el-Binâye fíş̧erhi'l-Hidâye (Beyrut: Dâru'l-Kütübü'l-'illmiyye, 2000), 4/9. Ayrıca bk. Kudûrî, et-Tecrid, 3/1440.

Muhammed b. Cerîr et-Taberî, Tehzî̉bü'l-âsâr ve tafșîlü'ś-şâbit 'an Resûlillâhi șallallāhu 'aleyhi ve sellem mine'l-ahbâr, thk. Mahmud Muhammed Şakir (Kahire: Matbaatü'l-Medenî, ts.), 1/388-394 (No. 653-669).

Her ne kadar başka hadisler Abdullah b. Mes`ud'un âşûrâ günü oruç tutmayı mubah gördüğü yönünde olsa da Alkâme'nin şu rivayetine nazaran Taberî müstehap gördüğü kanaatindedir: "Yılın hemen tüm günlerinde Abdullah b. Mes'ud'un yanına gittim. Ramazan haricinde sadece âşûrâ günü oruçlu olduğunu gördüm." bk. Taberî, Tehżîbü'l-âsârr, 1/391.

Taberî, Tehzîubül-âsârr, 1/394-395 (No. 670-676).

İbn Müflih, Kitâbü'l-fürû', 5/89-90.

Abdürrezzâk, el-Mușannef, 4/289 (No. 7847). 
mubah görmesidir. Çünkü eğer mekruh görse idi tutanları meneden ifadelerin aktarılması gerekirdi.

Taberî, Rasûlullah'ın (s.a.v.) ramazan orucundan önce âşûrâ orucunu emrettiğini, ramazan farz kılındıktan sonra önceki gibi emretmeyip kişileri serbest bıraktığını, ancak oruç tutmaya teşvik ettiğini, tutanın bir fazilet elde edeceğini, terk edenin ise kınanamayacağını söylemektedir. Mekruh gören sahâbînin ise bu orucun cahiliye döneminde tutulması nedeniyle onların bir ameline benzemekten kaçındıkları için böyle gördüklerini ifade etmektedir. ${ }^{66}$

Tüm mezhepler âşûrâ orucunun müstehap olup vacip olmadığında ittifak etmiştir. ${ }^{67}$ Ancak aralarında bazı farklılıklar vardır. İbn Rüşd el-Hafîd'e (ö. 595/1198) göre âşûrâ günü, oruç tutulmasının teşvik edildiği ve o günde orucun mendup olduğu hususunda mezheplerin ittifak ettiği bir gündür. ${ }^{68}$

Hanefilere göre âşûrâ orucu müstehaptır. ${ }^{69}$ Hanefilerin bir kısmına göre sadece âşûrâ günü oruç tutmak, Yahudilere benzeme nedeniyle mekruhtur. ${ }^{70}$ Ebû Yusuf'tan (ö. 182/798), Ehl-i kitaba muhalefet için, âşûrâ gününden önce ve sonra oruç tutmanın güzel görüldüğü nakledilmiştir. ${ }^{71}$

İbn Nüceym (ö. 970/1563), âşûrâ orucunun dokuzuncu günle birlikte tutulmasının sünnet; tek başına onuncu gün oruç tutmanın tenzihen mekruh olduğunu ifade etmiştir. ${ }^{72}$ İbn Âbîdin (ö. 1252/1836), ed-Dürrü'l-muhtar'daki bu görüşe yazdığı hâşiyede, âşûrâ orucunun müstehab olması görüşünü tercih etmiştir. ${ }^{73}$

Malikîlere göre âşûrâ günü oruç nafile olarak teşvik edilmiştir, mendubdur. ${ }^{74}$ Eşheb el-Kaysî, ${ }^{75}$ âşûrâ orucunun müstehap olduğunu söylemiştir. ${ }^{76}$ Ramazan'dan $^{\prime}$

66 Taberî, Tehzî́bü'l-âsâr, 1/396 (No. 677).

67 Ebü'l-Muzaffer İbn Hübeyre, İhtilâfü'l-e'immeti'l-ulemấ, thk. es-Seyyid Yusuf Ahmed (Beyrut: Dâru'l-Kütübü'l-'Ilmiyye, 2002), 1/258.

Ebü'l-Velîd İbn Rüșd Muhammed b. Ahmed (el-Hafîd), Bidâyetü'l-müctehid ve nihâyetüll-mukteșid (Kahire: Dâru'l-Hadîs, 2004), 2/70.

Ebu'l-Hasen (Hüseyn) Rüknülislâm Alî es-Suğdî, en-Nütef fi'l-fetâvâ, thk. Selâhaddin en-Nâhî (Amman - Beyrut: Dâru'l-Furkan - Müessesetü'r-Risâle, 1404/1984), 1/147. Ebû Bekr Alâüddîn es-Semerkandî, Tuhfetü'l-fukahâ' (Beyrut: Dâru'l-Kütübü'l-'İlmiyye, 1994), 1/343; Kâsânî, Bedâ'i'u'ș-șanâ'ic', 2/79; Zeynüddin er-Râzî, Tuhfetü'l-mülûk, thk. Abdullah Nezir Ahmed (Beyrut: Dâru'l-Beşâiru'l-İslâmiyye, 1417), 150. Burhâneddîn Mahmûd el-Buhârî, el-Muhîțü'l-Burhânî fi'l-fikhi'n-Nu'mânî, thk. Abdülkerim Sami, (Beyrut: Dâru'l-Kütübü'l-'ilmiyye, 2004), 2/394.

72 Zeynüddîn İbn Nüceym, el-Bahrü'r-râ'ik (b.y.: Dâru'l-Kütübü'l-İslâmiyye, ts.), 2/277.

73 Muhammed Emîn İbn Âbidîn, Reddü'l-muhtâr 'ale'd-Dürri'l-muhtâr (Beyrut: Dâru'l-Fikr, 1992), 2/374-375.

İbn Ebî Zeyd, Ebû Muhammed Abdullāh, Metnü'r-Risâle (b.y.: Dâru'l-Fikr, ts.), 148; en-Nevâdir ve'z-ziyâdât, 2/81; İbn Abdülber en-Nemerî, el-Kâfî fî fikhi ehli'l-Medîne, thk. Muhammed Muhammed Ehîd (Suud: Mektebetü'r-Riyâd el-Hadîse, 1980), 1/350; Ebu'l-Velid İbn Rüșd, elBeyân ve't-taḥ̂îll, 2/321.

Ebû Amr Eşheb b. Abdilazîz b. Dâvûd el-Kaysî el-Âmirî el-Ca'dî (ö. 204/820). Mâlikî fakihlerinin büyüklerindendir. İbn Ebî Zeyd, en-Nevâdir ve'z-ziyâdât, 2/75. 
sonra en faziletli oruç âşûrâ orucudur. ${ }^{77}$ Karâfî (ö. 684/1285), âşûrâ orucunun İmam Malik'e göre müstehab, İmam Şâfiî̀ye göre sünnet olduğunu söylemiş; ${ }^{78}$ başka bir Malikî fakihi İbn Cüzey (ö. 741//1340) ise sünnet demiştir. ${ }^{79}$ Mevvâk'a (ö. 897/1492) göre ise onuncu gün tutmak sünnet, dokuzuncu gün de tutmak müstehaptır. ${ }^{80}$ Haraşîyye (ö. 1101/1690) göre, Muharrem'in dokuzuncu ve onuncu günü oruç tutmak müstehaptır. Onuncu gün (âşûrâ) dokuzuncu günden daha faziletlidir. ${ }^{81}$

Şâfiîler de sünnet veya müstehap olduğu kanaatindedirler. Mâverdî (ö. 450/1058), onuncu gün tutmak sünnet, dokuzuncu gün ise müstehaptır, ${ }^{82}$ derken; Ebû İshak eş-Şîrâzî (ö. 476/1083), onuncu ve dokuzuncu gün oruç tutmak müstehaptır, görüşündedir. ${ }^{83}$ Âşûrâ orucunun, Muharrem'in dokuz ve onunda tutulma sebebi olarak iki husus söylenmiştir. Birincisi hilalin görülmesinde hata edilebilmesi sebebiyle onuncu günü kaçırmamak, ikincisi de Yahudilere muhalefettir. Şâfiî âlimi Râfiî (ö. 623/1226), buna göre dokuzunda tutulmaz ise on birinde tutmak da müstehap olur demektedir. ${ }^{84}$

Rûyânî (ö. 502/1108), dokuz ve onuncu gün oruç tutmanın müstehap olduğunu, onbirinci günün dokuzuncu günün yerine tutulamayacağını, âşûrâ orucunun dokuzuncu gün olduğunu söylemenin hata olduğunu söylemekte ve Kaffâl'in (ö. 365/976), Yahudilerin Muharrem'in onunda oruç tutmadıklarını, başka gün oruç tuttuklarını belirttikten sonra, "onlar cuma gününü değiştirdikleri gibi bunu da değiştirdiler", dediğini aktarmaktadır. ${ }^{85}$

Hanbelîlere göre de âşûrâ orucu müstehaptır. İbn Kudâme, âşûrâ orucunun Muharrem'in onu ve dokuzu olduğu hususundaki ihtilafı nakletmiştir. "Yahudilere muhalefet ediniz" ifadesine göre hem dokuzu hem de onunda tutmanın müstehap olduğunu söyleyen İbn Kudâme, Ahmed b. Hanbel'in "eğer ayın ilk gününde şüpheye düşerseniz üç gün oruç tutun" dediğini aktarmıştır. ${ }^{86}$

77 Ebu'l-Velid Muhammed b. Ahmed b. Rüşd (el-Cedd), el-Mukaddimâtü'l-mümehhidât, thk. Muhammed Haccî (Beyrut: Dâru'l-Ğarbi'l-İslâmî, 1988), 1/242 Muhammed el-Hattâb er-Ruaynî, Mevâhibü'l-celîl li-șerḥi Muḩtașarı Hualîl (b.y.: Dâru'l-Fikr, 1992), 2/403.

Ebü'l-Kāsım Muhammed İbn Cüzey, el-Kavânînü'l-fikhiyye fî telhîși mezhebi'l-Mâlikiyye (b.y.: y.y., ts.), 78.

Ebû Abdillâh Muhammed el-Mevvâk, et-Tâc ve'l-iklîl li-Muhtașarı Halîl (Beyrut: Dâru'l-Kütübü'l'İlmiyye, 1994), 3/313-319.

Muhammed b. Abdullah el-Haraşî, eș-Şerḥu'l-kebîr 'alâ Muhtașarı Halîl (Beyrut: Dâru'l-Fikr, ts.), 2/241.

Ebû İshak eş-Şirâzî, el-Mühezzzeb fî fiḳhi'l-İmâm eş-Şâficî (Beyrut: Dâru'l-Kütübü'l-'İlmiyye, ts.), 1/344; Muhammed b. Ahmed eş-Şâșî, Hilyetü'l-'ulemầ fî ma 'rifeti mezâhhibi'l-fukahâ', thk. Yasin Ahmed İbrahim (Beyrut: Müessesetü'r-Risâle, 1980), 3/176.

Ebu'l-Kāsım Abdülkerîm er-Râfi î, Fetḥu'l-'azîz fỉ Şerhịi'l-Vecîz (b.y.: Dâru'l-Fikr, ts.), 6/469.

Rûyânî, Bahru'l-mezhheb, 3/305.

İbn Kudâme, el-Mug̉nî, 3/177-178; Ebu'l-Ferec İbn Kudâme, eș-Șerhu'l-kebîr, 3/104-105. 
İbn Müflih, Muharrem ayında oruç tutmanın müstehap olduğunu, en faziletli gününün ulemânın çoğunluğuna ittibaen onuncu günde (âşûrâ günü), sonra da dokuzuncu gün olduğunu söylemektedir. ${ }^{87}$ Ahmed b. Hanbel'in Muharrem'in dokuz ve onuncu gün tutmayı emrettiğini, sözünün muktezasının sadece onuncu gün tutmanın mekruh olmasını gerektirdiğini, ancak mezhepteki görüşün tek başına onuncu gün oruç tutmanın mekruh olmadığı şeklinde olduğunu söyleyen İbn Müflih'e göre; Abdullah b. Abbas, tek başına Muharrem'in onunda oruç tutmanın mekruh olduğu görüşündedir. ${ }^{88}$

Buhûtî (ö. 1051/1641), âşûrâ orucu olarak Muharrem'in dokuz ve onunu birleştirmenin sünnet olduğunu, ancak sadece onuncu gün tutulmasının mekruh olmadığını, mezhepte tercih edilen hükmün bu olduğunu söylemiştir. ${ }^{89}$

İbn Hazm (ö. 456/1064), âşûrâ orucunu müstehap görmüş ve Muharrem'in dokuzunu kabul etmiştir. Eğer onuncu gün de oruç tutulursa güzel (hasen) olur demiştir. Delili Katâde hadisi ile İbn Abbas hadisidir. ${ }^{90}$

Hanefî fikhına göre hazırlanan ilmihâl kitaplarında âşûrâ orucunu sadece Muharrem'in onunda tutmanın tenzihen mekruh olduğu, dokuzu veya onbiri ile birlikte tutmanın müstehap olduğu kaydedilmiștir. ${ }^{91}$

Biz burada İbn Abbas'a isnad edilen ve Hanefîlerin esas aldığı, Yahudilere benzeme nedeniyle, tek başına Muharrem'in onunda oruç tutmanın mekruh olduğu görüşünü incelediğimiz için bununla ilgili hususları inceleyeceğiz. Acaba Yahudilerde böyle bir oruç var mıdır? Önceden vardı da sonra mı kaldırıldı? Hâlen yürürlükte midir? Bunun için Yahudilerin tuttukları oruçlara kısaca bakalım.

\section{Yahudi Oruçları ve Kutsal Günleri}

Yahudilerin üç tür orucu vardır. Ahd-i Atîk'te geçen veya işaret edilen oruçlar, hahamların emrettiği oruçlar ve özel oruçlar. ${ }^{92}$

Ahd-i Atik'te geçen veya işaret edilen oruçlar için Yahudi geleneğinde büyük oruçlar ve küçük oruçlar ayrımı vardır. Emrin kesinliği, süresinin uzun ve yasaklarının fazla olması nedeniyle Yom Kipur ve 9 Av günü (Tişa Beav) oruçları büyük oruçlardır. ${ }^{93}$

\footnotetext{
87 İbn Müflih, Kitâbü'l-fürû', 5/89-90.

88 İbn Müflih, Kitâbü'l-fürû', 5/91.

89 Mansûr b. Yûnus Buhûtî, Keşşâfü'l-ḳınâc ‘an (metn)i'l-ịknâ (Beyrut: Dâru'l-Kütübü'l- İlmiyye, ts.), 2/338-339.

90 Ebû Muhammed Alî b. Ahmed İbn Hazm, el-Muhallâ bi'l-âsâr (Beyrut: Dâru'l-Fikr, ts.), 4/437.

91 Ömer Nasûhi Bilmen, Büyük İslam İlmihâli, sad. Akif Dursun (İstanbul: Nuh Yay. 2015), 316; Ayrıca bk. H. Yunus Apaydın vd., İlmihâl [(Ankara: TDV Yay., 2003 (Dördüncü baskı)], 1/386.

92 Âdem Özen, Yahudilikte İbadet (İstanbul: Marmara Üniversitesi, Sosyal Bilimler Enstitüsü, Doktora Tezi, 1999), 182.

93 Muhammet Tarakçı, "Yahudilikte Oruç”, İlsam (Erişim 02.04.2020).
} 
Yasakları daha az ve süresi daha kısa olan küçük oruçlar ise Yahudilerin dördüncü ayı Tammuz'un 17'sinde Kudüs'ün düşman eline geçmesi anısına tutulan oruç (şivah asar be-tammuz); yedinci ay olan Tişrin'in 3'ünde Kudüs'te kalan Yahudi halkın önderliğini yapan Gedalya adındaki kişinin ölümü nedeniyle tutulan Gedalya Orucu (Tzom Gedalia); onuncu ay olan Tevet'in 10'unda, Kudüs'ün kuşatılması anısına tutulan oruç olan Tevet orucu (asarah be-tevet) ve 13 Adar günü tutulan Ester orucudur (Taanith Ester) ${ }^{94}$.

En büyük oruç kabul edilen ve müsteşrikler ile onları takip eden bazı yazarlarca âşûrâ orucu ile bağlantı kurulan Yom Kipur doğrudan Ahd-i Atik tarafından emredildiğ $i^{95}$ kabul edilen yegâne oruçtur. ${ }^{96}$ Yom Kipur kefâret günü demektir. Herhangi bir günle bağlantılı değildir. ${ }^{97}$ Yahudilerin dinî takvimine göre yedinci, medenî takvimine göre birinci ayın onunda tutulan bu oruç, arefe günü (9. gün) akşamından ertesi günün akşamına kadar yaklaşık 25 saat süren bir oruçtur. $\mathrm{Bu}$ sürede hiçbir şey yenilmez, içilmez, cinsî münasebette bulunulmaz, kozmetik kullanılmaz, yıkanılmaz ve dünyevî bir iş yapılmaz. ${ }^{98}$

İkinci büyük oruç olan Tişa Beav, esasen, Yahudi takvimine göre aynı günde vaki olan tapınağın birinci yıkılışı (MÖ. 587) ve ikinci yıkılışı (MS. 70) anısınadır. ${ }^{99}$ Bunun haricinde Yahudilere göre casusların vaad edilmiş topraklardan dönüşü (MÖ. 1313) de bu tarihtedir ve bu olaydan sonra Tanrı, İsrailoğulları'nı çölde 40 sene dolaştırmıştır. Romalılara karşı yapılan Bar Kohba İsyanı (MS. 133) bu günde yapılmış ve kaybedildiği için Betar Yahudileri aynı tarihte katledilmiştir. Bunun dışında modern zamanlarda da Yahudilerin başına gelen pek çok felaketin bu günde olduğu ifade edilmiştir. ${ }^{100}$

Hahamlar tarafından emredilen oruçlar: Tişrin ayının ilk on günü, ayın ilk pazartesi ve perşembesi ile Pesah ve Sukot bayramlarını takip eden pazartesi ve perșembe günleri, Kudüs'ün tahribine duyulan kederi ifade eden 17 Tammuz 9 Av arası üç yas haftası, Hz. Mûsâ'nın ölüm tarihi olan 7 Adar, her ayın son günü (Yom Kipur Katan), Pesah bayramı arefesinde doğan ilk erkek çocuklar için tutulan oruç,

Ali İhsan Yitik, "Oruç", TDV İslâm Ansiklopedisi (İstanbul: 2007), 33/414-415.

Şu ayete dayandırmaktadırlar: "RAB Musa’ya şöyle dedi: Yedinci ayın onuncu günü günahların bağışlanma günüdür. Kutsal bir toplantı düzenleyeceksiniz. İsteklerinizi denetleyecek, RAB için yakılan sunu sunacaksınız. 0 gün hiç iş yapmayacaksınız. Çünkü Tanrınız RAB’bin huzurunda günahlarınızı bağışlatacağınız bağışlanma günüdür. 0 gün isteklerini denetlemeyen herkes halkın arasından atılacaktır. 0 gün herhangi bir iş yapanı halkın arasından yok edeceğim. Hiç iş yapmayacaksınız. Yaşadığınız her yerde kuşaklar boyunca sürekli yasa olacak bu." (Kitab-ı Mukaddes (Erişim 31 Mayıs 2020), Lev. 23:26-31.)

Özen, Yahudilikte Ibadet, 179; Muhammad Akram, "Dinler Tarihi Açısından Yahudilik, Hristiyanlık ve İslam'da Orucun Anlamı ve Önemi”, Ramazan ve Oruç, ed. Berat Açıl vd. (İstanbul: Ümraniye Belediyesi, Haziran 2015), 46.

Salime Leyla Gürkan, Yahudilik, (İstanbul: İsam Yay., Dördüncü basım, Haziran 2012), 211-212.

Galip Atasağun, "Yahudilikte Dinî Sembol ve Kavramlar", Selçuk Üniversitesi İlahiyat Fakültesi Dergisi, 11/1 (2001), 141.

Akram, “Dinler Tarihi Açısından...”, 47.

Rika Kuriel, “Yahudiler Tişa Beav'da Neden Oruç Tutarlar”, Avlaremoz (Erişim 02.04.2020). 
Yahudi tarihindeki feci günler için tutulan oruçlardır. Bu günlerde dindar Yahudiler sabahtan akşama kadar oruç tutarlar.

Özel oruçlar ise yukarıdakiler ilaveten, Tora demeti düşürüldüğünde, ebeveynin ölüm yıldönümünde, damat ve gelin dügünlerine kadar tuttukları ve kâbus görüldüğünde tutulan oruçlardır. ${ }^{101}$

Yahudiler her hafta Şabat'ı (cumartesi gününü) bayram telakki ettikleri gibi, her takvim ayının ilk gününü de bayram kabul etmektedirler. Yıllık Yahudi bayramları ise Rabbanî ve onun devamı olan geleneksel Yahudiliğe göre yılbaşı kabul edilen Tişrî ayının bir ve ikinci günlerinde kutlanan Roş Aşana; Tişrî ayının 15. günü başlayan ve "Çardaklar Bayramı" olarak da bilinen Sukot; Kislev ayının 25. günü kutlanmaya başlayıp 8 gün süren Hanuka; Şevat ayının 15. günü kutlanan Tu Bişvat; Ester orucundan sonra Adar ayının 14. ve 15. günü kutlanan Purim; İbrânî takvimine göre Sivan ayının 6. ve 7. günleri kutlanan Şavuot ${ }^{102}$ ve İbranî takvimine göre Nisan ayının 15. günü kutlanmaya başlanan ve İsrail'de yedi gün diasporada sekiz gün süren Pesah'tır.

Bu bayramlardan âşûrâ ile bağlantısı kurulan Pesah bayramı süresince oruç tutulmaz ancak bayramı takip eden Pazartesi ve Perşembe oruç tutmak tavsiye edilmiştir. ${ }^{103}$ Aslında Pesah ${ }^{104}$ bir ilkbahar bayramıdır. ${ }^{105}$ Esası Filistin bölgesindeki arpa hasadı dönemi ile bağlantılıdır. ${ }^{106}$ Ancak Yahudî dinî metinlerinde bu bayramın, Hz. Mûsâ ve kavminin bu günde Mısır'dan çıktığı, kölelikten hürriyete geçtiği gün anısına kutlandığı ifade edilmektedir. ${ }^{107}$

$\mathrm{Bu}$ sayılan oruç ve bayramlar Filistin ve Babil bölgesinde yaşayan Yahudi toplulukları tarafından kabul edilen günlerdir. Nûh Arslantaş'ın tespitine göre, $\mathrm{Hz}$. Peygamber'in çağdaşı Yahudiler de hayatlarını Tevrat ve Talmud'un esaslarına göre tanzim eden cemaatler olup o dönemdeki Babil ve Filistin'de yaşayan Yahudi cemaatlerinden hiçbir farkları bulunmamaktadır. ${ }^{108}$ Bu sebeple Rasûlullah Medine'ye hicret ettiğinde oradaki Yahudilerin bu günlerine şahit olmuş olmalıdır.

Rivayetlere nazaran âşûrâ günü ile bağlantı kurulan bir oruç (Yom Kipur) ve bir bayram (Pesah) bulunmaktadır. Şimdi bu günlerin Rasûlullah Medine'ye hicret ettiği zaman hangi günlere denk geldiğini tespit etmeye çalışacağız.

\footnotetext{
101 Özen, Yahudilikte İbadet, 184-185.

102 Geniș bilgi için bk. Gürkan, Yahudilik, 209-216; Sargon Erdem, "Bayram", Türkiye Diyanet Vakfi İslâm Ansiklopedisi (Erişim 31 Mayıs 2020); Yusuf Altıntaş, "Musevi Dinî Bayramları ve Kutsal Günleri”, Türk Yahudileri (Erişim 31.05.2020); Sevivon (Erişim 31.05.2020). Gürkan, Yahudilik, 216.

Pesah, atlamak, geçmek, karşıya geçmek manalarına gelmektedir. Atasağun, Yahudilikte Dinî Sembol ve Kavramlar, 11/144.

Gürkan, Yahudilik, 213-214.

Özen, Yahudilikte İbadet, 225-226.

Nuh Arslantaş, "Hz. Peygamber'in Çağdaşı Yahudilerin İnanç-İbadet ve Dinî Hayatları ile İlgili Bazı Tespitler”, Marmara Üniversitesi İlahiyat Fakültesi Dergisi, 34 (2008), 92.
} 


\section{Medine Döneminde Âşûrâ Orucunun Yahudi Takvimine Göre Zamanı}

Yahudilere benzerliği tespit edebilmek için Yahudilerin tazim ettikleri gün ile âşûrâ arasında bir bağlantı olup olmadığını; bunun için de Yahudi takvimindeki kutsal günlerle âşûrâ gününün örtüşüp örtüşmediğini tespit etmek gerekmektedir. Bunun için öncelikle Yahudi ve Câhiliye takvimi hakkında kısaca bilgi verilecektir.

Güneş esaslı, ay esaslı ve ikisini bir arada kullanan takvimler olmak üzere dünyada kullanılan üç tür takvim vardır. Yaygın olarak kullanılan güneş takvimleri dünyanın güneş etrafında dönme süresini esas alarak oluşturulmuştur. Ay takvimleri ise ayın dünya etrafındaki dönüşünü esas almıştır. İkisinin karışımından oluşan aygüneş takvimleri ise esasta ay takvimini esas almakla birlikte güneş takvimine uyumlu olması için belli zamanlarda takvime ay veya gün eklenen takvimlerdir. Yahudilerin ve Câhiliye Araplarının kullandığı nesîlî takvim ay-güneş takvimleri sınıfındandır. ${ }^{109} \mathrm{Bu}$ takvimlerde genellikle, 19 güneş yılı dönüşümü esas alınmıştır. Aralarındaki farklılık on dokuz senelik dönüşüm içinde yedi kamerî ay ilavesinin hangi senelere ilave edileceği hususunda ortaya çıkmaktadır. Nesîli takvimlerin kökeni, Mezopotamya'da Babil'in ünlü hükümdarı Hammurabi (M.Ö. 1728-1686) öncesine değin gittiği tespit edilmiştir. ${ }^{110}$ Asurlularda hem ay yılı (lunar year) hem güneş yılının (solar year) kullanıldığı, ay yılı esaslı takvimlerine bazı yıllarda ay ekledikleri; bu yöntemin eski Mısırlılarda da uygulandığı ifade edilmiştir. ${ }^{111}$

Yahudilerin kullandığı İbrânî takvimi, araştırmacılara göre Mezopotamya kökenlidir. Ancak eski Mısır'dan da alınmış olabilir. Bu takvim Hz. Âdem'in yaratılışı ile başlar. Hahamlar tarafından Tevrat'ın verilerine göre Hz. Âdem'in yaratılışı hesap edilmiştir. Bu da M.Ö. 3761 yılına denk gelmektedir. Bu takvimde yıllar, M.Ö. 3761'den başlamak üzere, 19 Güneş yılından oluşan dönüşümlere ayrılır ve her bir dönüşümün 3, 6, 8, 11, 14, 16 ve 19'uncu yıllarında bir ay eklenerek, o yıllar 13 ay olur. Yani 19 yılda yedi ay ilave edilmiş olur. Artık (eklenen) aylar, şu andaki yılbaşı esasına göre yılın altıncı, dinî takvim esas alındığında sonuncu ay olan Adar'ın sonuna getirilir ve Veadar adını alır. ${ }^{112}$ Bunu yapmalarının kendilerince dinî sebebi, belli başlı bayramlarının özellikle de Pesah bayramının aynı mevsime gelmesini temin etmektir. Çünkü onlara göre Pesah'ın ilkbahar ayına gelmesi doğrudan Tanrı tarafından emredilmiştir. ${ }^{113}$ Aslında bu usulün hasat bayramları olan Pesah, Şavuot ve Sukot bayramlarının mevsimlerini korumak için çıkarıldığı anlaşılmaktadır. Bu sistem

A. Necati Akgür, "Takvim", Türkiye Diyanet Vakfi İslâm Ansiklopedisi (Erişim 31 Mayıs 2020). Kevser Başar, Câhiliye Dönemi Arap Takviminde Nesî (İstanbul: Marmara Üniversitesi, Sosyal Bilimler Enstitüsü, Yüksek Lisans Tezi, 2006), 18.

Neşet Çağatay, "Eski Çağlardan Bu Yana Zaman Ölçümü ve Takvim”, Ankara İlahiyat Fakültesi Dergisi, 22 (1978), 109.

A. Necati Akgür, "Nesi'li Takvimde Hz. Peygamber'in Doğumu ve Hicret Günleri", Türk Dünyası Araştırmaları, 84 (Haziran 1993), 64-45.

Nazlı Doenyas, "Artık yılda Purim ne zaman kutlanır?", Șalom (Erişim 4 Nisan 2020); Ebü'r-Reyhân elBîrûnî, el-Âsârrü'l-bâklye 'ani'l-ḳurûni'l-hâliye (Kahire: Mektebetü's-Sekâfe, 2008), 63. “Illkbahar ayını gözet ve Tanrın Așem Adına Pesah korbanı yap; çünkü Tanrın Așem seni Mısır’dan ilkbahar ayında çıkarmıștı." Tora Aftarat, 132, Sevivon (Erişim 31 Mayıs 2020). 
sebebiyle Yahudilerin tüm dinî günleri güneş takvimine göre yaklaşık bir aylık süre içerisinde gidip gelmektedir. ${ }^{114}$

Cahiliye Arapları da nesîli yani ay yılına zaman ekleme yapılan bir takvim kullanmaktadırlar. Bîrûnî (ö. 453/1061 [?]), Arapların nesî sistemini İslam'dan yaklaşık iki yüzyıl önce Yahudilerden aldığını söylemektedir. İsrailoğulları'nın tamamının ay-güneş takvimini birlikte kullandıklarını söyleyen Bîrûnî, 19 yılda yedi ay takvime ilave ettiklerini belirtmektedir. ${ }^{115}$ Muhammed Hamîdullah (1908-2002) ise bu tespite katılmamıştır. Ona göre Araplar bu takvimi İslam'dan dört yüz yıl önce kullanmaya başlamışlardı ve Yahudilerin karışık metodunu değil, Hammurabi'nin daha basit metodunu kullanmaktaydılar. ${ }^{116}$

Bîrûnî, Câhiliye Araplarının önceden daha sonra Müslümanların kullandığı şekliyle kamerî takvimi kullandığını, haccın yılın dört mevsimine de geldiğini, ancak sonra ticaretlerine uygun olan, güzel bir mevsime haccl sabitlemek isteyince komşuları olan Yahudilerden nesî işlemini yani kamerî takvime ay ekleme işlemini aldıklarını söylemektedir. Bunun için Kinâne kabilesinden bir Kalemmes tayin ettiklerini, onun her haccın sonunda sonraki ayı ilan ettiğini ifade etmiştir. ${ }^{117}$ Makrizî (ö. 845/1442) de Bîrûnî’yi tekrar etmiş ve nesî uygulamasını bazen üç yılda bazen de iki yılda bir ay ekleyerek yaptıklarını söylemiștir. ${ }^{118}$

Hamidullah, Yemen'de Kinde Kralının İslam'dan evvel Mekke şehir devletinde bir "Takvim Nazırlığı" ihdas ve bu nazırlığı Basra körfezinde oturan Temim aşiretine tahsis ettiğini, bu makamın irsî olarak geçtiğini, bu kişilerin her sene Mekke'de İslam öncesi hac ziyareti zamanında gerekli tebliğlerde bulunduklarını ve bu durumun birkaç yüzyıl devam ettiğini söylemekte ve Kinde'nin güneyde, Temim aşiretinin doğuda olması ve Mekke'nin Arap yarımadasının batısında bulunması sebebiyle hadiselerin sadece Mekke'den değil, her taraftan tetkik edildiğini gösterdiğini ifade etmektedir. ${ }^{119}$ Yine Hamidullah'ın tespitine göre Rasûlullah (s.a.v.) son üç ay hariç hayatının tamamını takvim hususunda eski usule göre geçirmiştir. ${ }^{120}$

Arapların nesîli takvimi Veda Haccında iptal edilmiştir. Bîrûnî, Allah Rasûlü'nün, nesîyi ilga etmek için Veda Haccını beklemesinin sebebinin, Veda

114 Yahudi takvimi ayrıntıları için bk. Tracey R Rich, “Jewish Calendar”, Jewfaq (Erişim 4 Nisan 2020).

115 Bîrûnî, el-Âsârü'l-bâk klye, 14.

116 Muhammed Hamidullah, "Hicri Takvim ve Tarihi Arkaplanı", çev. Kasım Şulul, Uludağ Üniversitesi İlahiyat Fakültesi Dergisi, 9/9 (2000), 672.

117 Bîrûnî, el-Âsârü'l-bâklye, 74-75.

118 Takıyyüddîn Makrîzî, Imtâ 'u'l-esmấ bimâ li'r-resûl mine'l-ebnẩi (enbẩi) ve'l-ahvâll ve'l-ḥafede ve'lmetấ, thk. Muhammed Abdülhumeyd en-Nüseymî (Beyrut: Dâru'l-Kütübü'l-'Illmiyye, 1999) 14/315-316.

119 Muhammed Hamidullah, “İslamiyette Niçin Ay Takvimi Kullanılır”, İslam Düşüncesi, 1/1 (1967), 51.

Hamidullah, “Hicri Takvim ve Tarihi Arkaplanı”, 672. 
Haccının yapıldığı sene ayların gerçek yerlerine denk gelmesi olduğunu söyler. ${ }^{121}$ Yani nesî yapılmış sene ile nesî yapılmamış senenin ayları birbiri üzerine çakışmıștır.

Hamidullah, 19 yıl yerine 30 yıllık bir döngü kabul etmiștir. ${ }^{122}$ Ancak Necati Akgür buna katılmamış, 19 yıllık döngünün daha doğru olduğunu söylemiştir ki, ${ }^{123}$ hesaplamalar Necati Akgür'ü haklı çıkarmaktadır.

Necati Akgür'ün açıklamalarına göre, güneş takvimlerinin işleyiş̧inin belli bir kurala bağlı olmaları nedeniyle, binlerce yıl öncesinin herhangi bir gününün bile, Pazartesi, Salı, ... gibi gün adları düzenlenecek dökümler yardımıyla bulunabilmektedir. ${ }^{124}$ Ancak Ay (Hicrî) takviminde ayların 29 ya da 30 gün çekmesi ve bu işleyişin sırasız ve düzensiz oluşu dolayısıyla, bir kurala bağlanamaması, yapma bir kurala bağlamanın ise dinimizce yasaklanmış olması sebebiyle, güneş takvimlerinin aksine, Ay takvimimizde geçmiş yıllardaki günlerin dökümlerinin yapılması ve dolayısıyla gün adlarının tam olarak belirlenmesi ile Rumi/miladi karşılıklarının bulunabilmesi imkânı bulunmamaktadır. Bununla birlikte, tarih araştırıcılarının gereksinim duydukları hicri-Rumi-miladi çevirme cetvellerinin düzenlenmesi, hicri takvimin, yapma ve uyduruk da olsa, birtakım kurallara bağlanmasını gerektirmektedir. İşte bu yüzden, âlimler dinî günlerin belirlenmesinde kullanılmak üzere değil, ancak tarihçilerce kullanılsın diyerek, Hicrî takvimi yapma birtakım kurallara bağlayıp, bir kuramsal Hicrî takvim oluşturma yoluna gitmişlerdir. Ancak bu cetveller, gerçeği tam olarak yansıtmadıkları için, gün adının verilmediği/bilinmediği durumlarda, bir ya da iki günlük bir yaklaşım/yanılgı ile çalışmaktadır. Gün adının bilinir olması durumundaysa gün karşlıkları kesinlik kazanmaktadır. ${ }^{125}$

$\mathrm{Bu}$ açıklamalar muvacehesinde Rasûlullah'ın hicret tarihi ve Medine dönemindeki âşûrâ günleri yani 10 Muharrem'in Miladî ve İbranî takvime göre hangi günlere geldiğini tespit etmeye çalıştığımızda kuramsal olarak hazırlanan Hicrî takvime göre şöyle bir tablo ortaya çlkmaktadır: ${ }^{126}$

Tablo 1: Kuramsal Hicrî takvime göre âşurâ gününün tarihleri

\begin{tabular}{lllll}
\hline Gün & Hicrî Takvim & $\begin{array}{l}\text { Milâdî } \\
\text { Takvim }\end{array}$ & $\begin{array}{l}\text { İbrânî } \\
\text { Takvim }\end{array}$ & $\begin{array}{l}\text { Yakın Yahudi } \\
\text { Dinî günü }\end{array}$ \\
Hicret & 12 Rebiulevvel 1 & 24 Eylül 622 & 11 Tişri 4383 & Yom Kippur \\
Âşûrâ & 10 Muharrem 2 & $\begin{array}{l}14 \text { Temmuz } \\
\text { 6 A Av 4383 }\end{array}$ & Tişa Beav \\
& & 623 & & \\
\hline
\end{tabular}

Bîrûnî, el-Âŝâü'l-bâklyye, 75; Bașar, Câhiliye Dönemi Arap Takviminde Nesî, 54.

Hamidullah, "Hicri Takvim ve Tarihi Arkaplanı”, 674.

Akgür, "Nesi'li Takvimde...", 68-69.

Akgür, "Nesi'li Takvimde...", 60.

Akgür, “Nesi'li Takvimde...”, 62.

Hicrî takvime miladiye çevirmek için Türk Tarih Kurumu internet sitesindeki tarih çevirme kılavuzu; miladî takvimi İbranî takvimine çevirmek için de Sevivon'un sitesindeki takvim çevirici kullanılmıştır.
} 


\begin{tabular}{|c|c|c|c|c|c|}
\hline \multirow[t]{2}{*}{ Âşûrâ } & \multirow[t]{2}{*}{10 Muharrem 3} & 3 & \multirow[t]{2}{*}{ Temmuz } & \multicolumn{2}{|l|}{ Tammuz } \\
\hline & & 624 & & 4384 & \\
\hline \multirow[t]{2}{*}{ Âşûrâ } & \multirow[t]{2}{*}{10 Muharrem 4} & 22 & \multirow[t]{2}{*}{ Haziran } & \multirow[t]{2}{*}{6 Sivan 4385} & Şavuot \\
\hline & & 625 & & & \\
\hline \multirow[t]{2}{*}{ Âşûrâ } & \multirow[t]{2}{*}{10 Muharrem 5} & 11 & Haziran & Tammuz & \\
\hline & & 626 & & 4386 & \\
\hline Âşûrâ & 10 Muharrem 6 & $1 \mathrm{H}$ & ziran 627 & 8 Sivan 4387 & Şavuot \\
\hline Âşûrâ & 10 Muharrem 7 & $20 \mathrm{I}$ & Iayıs 628 & 8 Sivan 4388 & Şavuot \\
\hline Âşûrâ & 10 Muharrem 8 & $10 \mathrm{I}$ & Iayıs 629 & 9 Iyyar 4389 & \\
\hline Âşûrâ & 10 Muharrem 9 & 291 & isan 630 & 8 Iyyar 4390 & \\
\hline Âşûrâ & 10 Muharrem 10 & $18 \mathrm{I}$ & isan 631 & 8 Iyyar 4391 & \\
\hline Âşûrâ & 10 Muharrem 11 & $7 \mathrm{Ni}$ & $\operatorname{san} 632$ & 8 Nisan 4392 & Pesah \\
\hline Ras. & 13 Rebiulevvel & $8 \mathrm{H}$ & ziran 632 & 11 Sivan 4392 & Şavuot \\
\hline Vefatı & 11 & & & & \\
\hline
\end{tabular}
Pazartesi'ye gelmediğini belirttikten sonra, Hz. Peygamber'in Hicret'i sırasında, 8 Rebiülevvel 1 = 20 Eylül 622 Pazartesi günü Medine yakınlarındaki Kuba'ya vardığını, 12 Rebiülevvel 1 = 24 Eylül 622 Cuma günü de Medine'yi onurlandırdıklarını söylemektedir. ${ }^{127}$

Necati Akgür'e göre bu belirleme 16 Temmuz 622 Cuma başlangıçlı takvime göredir. 15 Temmuz 622 Perşembe başlangıçlı dökümlere göre bu tarihler: 9 Rebiülevvel 1 = 20 Eylül 622 Pazartesi; 12 Rebiülevvel 1 = 23 Eylül 622 Perşembe olmalıdır. ${ }^{128}$

Ancak bu hesaplama nesîyi dikkate almayan bir hesaplamadır. Muhammed Hamidullah, nesîyi dikkate alarak Rasûlullah'ın Medine'ye varışını hicri 12 Rebiulevvel 1, miladi olarak 31 Mayıs 622 Pazartesi olarak vermektedir. Buna göre 1 Muharrem 1'ini de 21 Mart 622 Pazar olarak tarihlemektedir. ${ }^{129} 21$ Mart 622, İbrânî takviminde 1 Nisan 4382 yılına gelmektedir.

Akgür'ün hesaplamasına göre ise hicret 12 Rebiülevvel 1, Nesîli takvimde 12 Zilkade H.Ö. 1'e, o da Milâdî takvimde 28/29 Mayıs 622 Cuma/Cumartesiye isabet etmektedir. ${ }^{130}$

Necati Akgür'ün tablosuna göre 10 Muharrem'ler şu şekildedir:

Tablo 2: Nesîli Hicrî takvime göre âşurâ gününün tarihleri

\begin{tabular}{lll}
\hline Nesîli Takvim & \multicolumn{1}{c}{ Hicrî Takvim } & Milâdî Takvim \\
\hline 127 & Gazi Ahmed Muhtar Paşa, Islahut-Takvim (Mısır: Muhammed Efendi Matbaası, 1308), 9-10. \\
128 & Akgür, "Nesi'li Takvimde..., 79. \\
129 & Hamidullah, "Hicri Takvim ve Tarihi Arkaplanı", 685. \\
130 & Akgür, "Nesi'li Takvimde...", 79-80.
\end{tabular}




\section{(15/16 Temmuz'a}

$$
\text { göre) }
$$

$\begin{array}{ll}10 \text { Muharrem 1 } & \text { 10 Ramazan H.Ö. 1 } \\ 10 \text { Muharrem 2 } & \text { 10 Ramazan 1 } \\ 10 \text { Muharrem 3 } & \text { 10 Şevval 2 } \\ 10 \text { Muharrem 4 } & \text { 10 Şevval 3 } \\ 10 \text { Muharrem 5 } & \text { 10 Zilkade 4 } \\ 10 \text { Muharrem 6 } & \text { 10 Zilkade 5 } \\ 10 \text { Muharrem 7 } & \text { 10 Zilkade 6 } \\ 10 \text { Muharrem 8 } & \text { 10 Zilhicce 7 } \\ 10 \text { Muharrem 9 } & \text { 10 Zilhicce 8 } \\ \text { 10 Muharrem 10 } & \text { 10 Zilhicce 9 } \\ 10 \text { Muharrem 11 } & -\end{array}$

29/30 Mart 622

9/10 Nisan 4382

18/19 Mart 623

8/9 Nisan 4383

5/6 Nisan 624

26/27 Mart 625

7/8 Nisan 4384

8/9 Nisan 4385

13/14 Nisan 625

8/9 Iyyar 4386

2/3 Nisan 627

22/23 Mart 628

7/8 Nisan 4387

10/11 Nisan 629

31/1 Nisan Mart 630

20/21 Mart 631

7/8 Nisan 632
8/9 Nisan 4388

9/10 Nisan 4389

9/10 Nisan 4390

9/10 Nisan 4391

8/9 Nisan 4392

Takvim hesaplamalarındaki hatalar olduğunu dikkate alırsak, kuramsal olarak hazırlanan hicrî takvime göre yapılan çevirmelerde (Tablo 1) âşûrâ ile Yahudi oruçlarından sadece Tişa Beav hicretin ikinci senesinde çakışmakta; hadislerde geçen Pesah bayramı ile ise sadece Rasûlullah'ın vefat senesi olan hicretin on birinci senesinde çakışmaktadır. Bazı yıllar ise Şavuot bayramı ile çakışmaktadır. Ancak rivayetlerde bu bayramla ilgili ifadeler yer almamaktadır. Nitekim bu çevirmelere göre hesap yapan bir Yahudi yazar aradaki çelişkiyi fark etmiş ve âşûrâ orucu ile Hz. Süleyman Mabedi'nin birinci ve ikinci yıkılışlarının anısına tutulan Tişa Beav orucunun çakıştığı kanaatine vararak, hadislerde geçen Firavun'un zulmünden kurtulma ile ilgili ifadelere, "Anlaşllan, Medine Yahudileri, "Hz. Süleyman Mabedi'nin yıkılışının yasını” tutuyoruz demektense “Tanrı'nın İsrâiloğulları'nı Firavun'un şerrinden kurtarışının orucunu tutuyoruz" demeyi yeğlemişler" açıklamasını

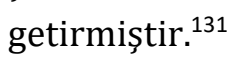

Nesîli takvime göre yapılan hesaplamada (Tablo 2) ise dikkat edilirse beşinci hicret yılı hariç bütün yıllarda Pesah bayramı günlerine yakın günler çıkmaktadır. Hesaplamada hata olduğunu da dikkate alırsak, Rasûlullah'ın (s.a.v.) Medine'ye hicret ettikten sonra ilk Muharrem'in onunda Yahudilerin büyük coşkuyla kutladığı Pesah bayramına şahit olduğu, bunun üzerine bu bayramın sebebini ve ne yaptıklarını sorduğu anlaşılmaktadır. Anlaşılan dindar Yahudiler ve hahamlar Pesah'ı takip eden pazartesi ve perşembe orucunu da ön plana çlkararak buna şükür için oruç tuttuklarını da söylemiş olmalıdırlar.

Ebû Mûsâ el-Eş'arî'den nakledilen bayramla ilgili rivayetler bunu teyit etmektedir. Ayrıca Rasûlullah'ın vefat yılında olduğu anlaşılan "inşallah önümüzdeki 131 Denis Ojalvo, “İslam'da âşûrâ orucu - Yahudiler'de Hz. Süleyman Mabedi'nin yıkılışının yası
orucu”, Şalom (Erişim 2 Nisan 2020). 
yll dokuzuncu gün tutarız" dediğini ifade eden hadiste de "Yahudi ve Hristiyanların bu güne tazim ettiği" ifade edilmiş, oruç tuttukları tasrih edilmemiştir.

Bununla birlikte bu hesaplamalara bakmadan bizde de bazı araştırmacılar Medine'de Yahudilerin âşûrâ günü tuttukları orucun Yom Kipur orucu olduğunu ${ }^{132}$, bazıları da âşûrânın Yom Kipur'dan alındığını iddia etmişlerdir. ${ }^{133}$

\section{Sonuç}

Rasûlullah'ın (s.a.v.) Medine'ye hicret ettikten sonra âşûrâ orucunu emrettiği hususunda ulemânın ittifakı vardır. Bunun kuvvetli sünnet mi yoksa farz olarak mı emredildiği hususunda kuvvetli görüş farz olarak emredildiğidir.

Bu orucu kimlerin tuttuğu hususuna gelince, Nevevî, bu husustaki hadislerden çıkan sonuç, âşûrâ orucu cahiliyede Kureyş kâfirleri ile diğer müşriklerin ve Yahudilerin oruç tuttuğu bir gündü. İslam gelince bunu tekit etti. Ramazan farz kılınınca bu tekit hafifletildi ancak oruç müstehap olarak kaldı, demektedir. ${ }^{134}$

Rasûlullah'ın Yahudilere sorması ile ilgili olarak da özetle, "Rasûlullah (s.a.v.) Mekke'de iken Kureyşlilerle birlikte oruç tutuyordu. Medine'ye gelince bugünde Yahudilerin de oruç tuttuğunu gördü. Sadece Yahudilerin haberine istinaden değil de, ya vahiy, ya tevatür ya da içtihadı ile orucu tutmaya devam etti" demektedir. ${ }^{135}$

Rivayetlerden bizim anladığımız, âşûrâ orucu Mekke'de tutulmakta ve bunun büyük ihtimalle Hz. İbrahim ve Hz. İsmail'e kadar uzanan bir geçmişi bulunmaktadır. Nûh'un (as) gemiden indiği gün rivayeti esas alınırsa, bu orucun köklerinin Hz. Nûh'a kadar gittiği dolayısıyla âşûrâ orucunun Hz. Nûh'tan itibaren bütün Sâmî dinlerde mevcut olan bir oruç olduğu söylenebilir. Yahudilere emredilen Yom Kipur orucu belki de bu oruçtur. Yom Kipur orucunun herhangi bir sebebe bağlanmamış olması, doğrudan emredilen bir oruç olması bu ihtimali akla getirmektedir. Ancak Yahudiler de nesî yaptığı ve ay takvimine göre belirlenmiş oruçların tarihini değiştirdikleri için bunu tespit etme imkânı bulunmamaktadır. Eğer Yom Kipur, Muharrem'in onunda tutulması gereken bir oruç ise, önceki peygamberlere emredilen bir orucun $\mathrm{Hz}$. Mûsâ'ya da emredildiğini söylemek gerekmektedir. Bu sebeple âşûrâ orucu Yahudilerden alınan bir oruç değil, "Ey iman edenler! Oruç sizden önce gelip geçmiş ümmetlere farz kılındığı gibi size de farz kılındı." ${ }^{136}$ ayeti çerçevesinde farklı ümmetlere emredilen bir oruç olmaktadır. Ramazan farz kılınana kadar Rasûlullah'a da bu oruç emredilmiş olmalıdır. Nevevî̀nin söylediği üç ihtimalden rivayetlere en uygun olanı vahiy yoluyla bunun emredilmiş olmasıdır.

\footnotetext{
132 Tarakçı, "Yahudilikte Oruç".

133 Eyüp Baş, "Așûre Günü, Tarihsel Boyutu ve Osmanlı Dinî Hayatındaki Yeri Üzerine Düşünceler", Ankara Üniversitesi İlahiyat Fakültesi Dergisi, 45/1 (2004), 171-172. 
Medine'ye hicretten sonra âşûrâ orucu günlerinde Yahudilerin Pesah bayramını yapması, bu günlere olan hürmetleri, Yahudilerle iç içe olan Müslümanların kafasını karıștırmış olmalıdır. Bunun üzerine Rasûlullah'ın Yahudilerin söylediği gerekçeyi reddetmeden Müslümanlara oruç tutmayı emretmesi, böyle bile olsa âşûrâ orucunun tutulması gerektiğini anlatmaktadır. Daha sonraki yıllarda özellikle Hayber'de kalan Yahudilerin âşûrâ ile yakın günlerde bu bayramı kutlamaya devam etmesi; Yahudilere muhalefetin gerekli olduğunu düşünen sahâbîlerin bu hususta Rasûlullah'a başvurmalarını, onun da bunun üzerine "o zaman dokuzunda da tutalım" demesini intaç etmiş olmalıdır. Bir ihtimal olarak Medine Yahudilerinin Pesah bayramlarını veya oruçlarını Muharrem'in onunda tuttuğu da akla gelebilir. Ancak yukarıda geçtiği üzere Rasûlullah'ın yaşadığı bölgede yaşayan Yahudilerin Filistin bölgesinde yaşayan Yahudilerden bir farkı yoktur.

Bu açıklamalardan da anlaşıldığı üzere Müslümanların Muharrem'in onunda tuttuğu âşûrâ orucu ile Yahudilerin herhangi bir orucu çakışmamaktadır. Ayrıca Yahudiler âşûrâ gününe tazim de etmemektedirler. Medine'de hicretin ilk on yılında iki tarafın da kullandığı nesîli takvim sebebiyle âşûrâ günü ile Pesah bayramı günlerinin çakışmasından kaynaklanan bir durum ortaya çıkmış, bunu da Müslümanların bir bölümü Yahudilerin âşûrâ gününe tazimi olarak yorumlamıştır. Medine Yahudilerinin de Müslümanları kendilerini taklit ediyor göstermek için, âşûrâ orucu ile kendi günleri arasında bir bağlantı olmadığını söylemedikleri anlaşılmaktadır. Kaldı ki Medine Yahudilerinin âşûrâya tazimle oruç tuttuğunu kabul etsek bile daha sonraki dönemlerde ve zamanımızda böyle bir durum bulunmamaktadır.

Netice olarak âşûrâ orucunun Muharrem'in onunda tutulması sünnettir. Buna dokuzuncu veya onbirinci gün ekleme şartı yoktur. Sadece onuncu gün tutmak mekruh değildir; aksine sünnettir. Eğer dokuzuncu gün de tutmak isteyen olursa bu fazilettir. Onuncu günü kaçırmamak gerekçesi ile dokuz ve onuncu hatta onbirinci günü oruçlu geçirme fetvası, Yahudilere benzememek gerekçesinden daha kuvvetlidir.

\section{Kaynakça}

Abdürrezzâk San'ânî, Ebû Bekir Abdurrezzâk b. Hemmâm b. Nâfî. el-Mușannef, thk. Habîburrahman el-A'zemî. 11 Cilt. Hind: el-Meclisü'l-İlmî, 1403.

Ahmed b. Hanbel, Ebû Abdillâh Ahmed b. Muhammed b. Hanbel eş-Şeybânî, el-Müsned, thk. Şuayb Arnavud vd. 45 Cilt. Beyrut: Müessesetü'r-Risâle, 1421/2001.

Akgür, A. Necati. "Takvim". Türkiye Diyanet Vakfı İslâm Ansiklopedisi. Erişim 31 Mayıs 2020. https://islamansiklopedisi.org.tr/takvim

Akgür, A. Necati. “Nesi'li Takvimde Hz. Peygamber'in Doğumu ve Hicret Günleri”. Türk Dünyasl Araştırmaları 84 (Haziran 1993), 59-90.

Akram, Muhammad. "Dinler Tarihi Açısından Yahudilik, Hristiyanlık ve İslam'da Orucun Anlamı ve Önemi". Ramazan ve Oruç. ed. Berat Açll vd. 45-62. İstanbul: Ümraniye Belediyesi, Haziran 2015. 
Altıntaş, Yusuf, "Musevi Dinî Bayramları ve Kutsal Günleri”, Türk Yahudileri. Erişim 31 Mayıs 2020. http://www.turkyahudileri.com/index.php/tr/yahudilik/106-musevi-dinibayramlari-ve-kutsal-gunleri.

Apaydın, H. Yunus vd. İlmihâl. 2 Cilt. Ankara: Türkiye Diyanet Vakfı Yayınları, Dördüncü baskı, 2003.

Arslantaş, Nuh. “Hz. Peygamber'in Çağdaşı Yahudilerin İnanç-İbadet ve Dinî Hayatları ile İlgili Bazı Tespitler”. Marmara Üniversitesi İlahiyat Fakültesi Dergisi 34 (2008), 55-92.

Âsım Efendi. Mütercim, Kâmus Tercümesi. 4 Cilt. İstanbul: Bahriye Matbaası, 1305.

Atasağun, Galip. "Yahudilikte Dinî Sembol ve Kavramlar". Selçuk Üniversitesi İlahiyat Fakültesi Dergisi 11/1 (2001), 125-156.

Aynî, Ebû Muhammed (Ebu's-Senâ) Bedrüddîn Mahmûd b. Ahmed b. Mûsâ b. Ahmed, el-Binâye fí șerhi'l-Hidâye. 13 Cilt. Beyrut: Dâru'l-Kütübü’l-İlmiyye, 2000.

Aynî, Ebû Muhammed (Ebu's-Senâ) Bedrüddîn. 'Umdetü'l-ḳārî fî şerḥi Șahîhịi'l-Buhârrî. 25 cilt. Beyrut: Dâru İhyâi't-Türâsi'l-'Arabî, ts.

Baş, Eyüp. "Așûre Günü, Tarihsel Boyutu ve Osmanlı Dinî Hayatındaki Yeri Üzerine Düşünceler”. Ankara Üniversitesi İlahiyat Fakültesi Dergisi 45/1 (2004), 167-190.

Başar, Kevser. Câhiliye Dönemi Arap Takviminde Nesî. İstanbul: Marmara Üniversitesi, Sosyal Bilimler Enstitüsü, Yüksek Lisans Tezi, 2006.

Beyhakî, Ebû Bekr Ahmed b. el-Hüseyin b. Ali. Şu'abü'l-îmân. thk. Abdülalî Abdülhamid. 14 Cilt. Riyad: Mektebetü'r-Rüșd, 2003.

Bilmen, Ömer Nasûhi. Büyük İslam İlmihâli. sad. Akif Dursun. İstanbul: Nuh Yayınları, 2015.

Bîrûnî, Ebu'r-Reyhân Muhammed b. Ahmed. el-Âsârü'l-bâklye 'ani'l-kurûni'l-hâaliye. Kahire: Mektebetü's-Sekâfe, 2008.

Buhârî, Muhammed b. İsmail b. İbrahim. el-Câmi ‘u'ṣ-șaḥịh, thk. Muhammed Züheyr b. Nâsır. 9 Cilt. b.y.: Dâru Tavki'n-Necât, 1422.

Buhûtî, Mansûr b. Yûnus. Keşşâfü'l-kıınâ' 'an (metn)i'l-İknâ. 6 Cilt. Beyrut: Dâru'l-Kütübü'lİlmiyye, ts.

Burhâneddin Buhârî, (Burhânü'ş-Şerîa) Mahmûd b. Ahmed b. Abdilazîz b. Ömer el-Buhârî elMergīnânî. el-Muhîțü'l-Burhânî fi'l-fiḳhi'n-Nu'mânî. thk. Abdülkerim Sami. 9 Cilt. Beyrut: Dâru'l-Kütübü'l-İlmiyye, 1424/2004.

Cessas, Ebû Bekir Ahmed b. 'Alî er-Râzî. Şerḥu Muhtașari'ț-Ṭahânî. 8 Cilt. Beyrût: Dâru'lBeşâ'iri'l-İslâmiyye, 2010.

Çağatay, Neşet. “Eski Çağlardan Bu Yana Zaman Ölçümü ve Takvim”. Ankara İlahiyat Fakültesi Dergisi 22 (1978), 105-138.

ed-Derviş, Macid Ahmed Niyazi. 'Âşûrâ fi'ş-şeria've't-tarîh. Trablus-Lübnan: Dâru'l-İlim ve'lUlemâ, 1436/2014.

Doenyas, Nazlı, “Artık yılda Purim ne zaman kutlanır?”, Şalom. Erișim 4 Nisan 2020. http://www.salom.com.tr/arsiv/haber-89969artik yilda purim ne zaman kutlanir.html

Ebû Dâvûd, Süleymân b. el-Eş'as b. İshâk es-Sicistânî el-Ezdî. Sünen. thk. Muhammed Muhyiddin Abdülhamid. 4 Cilt. Beyrut: el-Mektebetü'l-Asriyye, ts.

Ebû İshak eş-Şirâzî, Cemâlüddîn İbrâhîm b. Alî b. Yûsuf. el-Mühezzzeb fî fikhi'l-İmâm eş-Şâfi î. 3 Cilt. Beyrut: Dâru'l-Kütübü'l-İlmiyye, ts.

Ebu Muhammed Ali b. Zekeriyya el-Munbecî, el-Lübâb fi'l-Cem'i beyne's-Sünneti ve'l-Kitâb, thk. Muhammed Fadl Abdülaziz. 2 Cilt. Dımeşk: Dâru'l-Kalem, 1994.

Ebû Yusuf, Ya'kūb b. İbrâhîm b. Habîb b. Sa'd el-Kûfî. Kitâbü'l-Âsâr. thk. Ebu'l-Vefâ. Beyrut: Dâru'l-Kütübü'l-İlmiyye, ts. 
Ebu'l-Velid İbn Rüşd, Muhammed b. Ahmed b. Ahmed el-Kurtubî el-Endelüsî el-Cedd. elMukaddimâtü'l-mümehhidât thk. Muhammed Haccî. 3 Cilt. Beyrut: Dâru'l-Ğarbi'lİslâmî, 1988.

Ebu'l-Velid İbn Rüşd el-Cedd. el-Beyân ve't-taḥ̣̂̂l, thk. Muhammed Haccî vd. 19 Cilt. Beyrut: Dâru'l-Garbi'l-İ̇lâmî, 1988.

Elbânî, Ebû Abdurrahman Muhammed Nasîruddin b. el-Hâc Nûh b. Necâti b. Âdem. Daĩ fu Câmi'i's-Sagîir, b.y.: el-Mektebü'l-İslâmî, ts.

Erdem, Sargon, "Bayram". Türkiye Diyanet Vakfi İslâm Ansiklopedisi. Erişim 31 Mayıs 2020. https://islamansiklopedisi.org.tr/bayram\#1

eş-Şâşî, Ebû Bekr Fahrü'l-islâm Muhammed b. Ahmed b. el-Hüseyn. Hilyetü'l-'ulemâ' fí ma' rifeti mezâhibi'l-fukahầ. thk. Yasin Ahmed İbrahim, 3 Cilt. Beyrut: Müessesetü'r-Risâle, 1980.

Ezherî, Ebû Mansûr Muhammed b. Ahmed b. Ezher el-Ezherî el-Herevî. Tehzî́bü'l-luġa. thk. Muhammed Ivad. 15 Cilt. Beyrut: Dâru İhyâi't-Türâsi'l-Arabiyye, 2001.

Ezrâkî, Ebü'l-Velîd Muhammed b. Abdillâh b. Ahmed b. Muhammed. Ahbâru Mekke ve mâ câ’e fîhâ mine'l-âsârr. thk. Rüşdi es-Sâlih. 2 Cilt. Beyrut: Dâru Endülüs, ts.

Gazi Ahmed Muhtar Paşa. Islahut-Takvim. Mısır: Muhammed Efendi Matbaası, 1308.

Gürkan, Salime Leyla. Yahudilik, İstanbul: İsam Yay., Dördüncü basım, Haziran 2012.

Hâkim, Ebû Abdillâh Muhammed b. Abdillâh b. Muhammed el-Hâkim en-Nîsâbûrî. elMüstedrek ale'ș-Ṣahîhayn. thk. Mustafa Abdülkadir Ata'. 4 Cilt. Beyrut: Dâru'lKütübü'l-İlmiyye, 1990.

Hamidullah, Muhammed. "Hicri Takvim ve Tarihi Arkaplanı". çev. Kasım Şulul. Uludağ Üniversitesi Illahiyat Fakültesi Dergisi 9/9 (2000), 671-685.

Hamidullah, Muhammed. "İslamiyette Niçin Ay Takvimi Kullanılır". İslam Düşüncesi 1/1 (1967), 50-54.

Haraşî, Ebû Abdillâh Muhammed. eş-Şerḥu'l-kebîr 'alâ Muhttașarı Halîl. 8 Cilt. Beyrut: Dâru'lFikr, ts.

Hattâb, Şemsüddin Ebû Abdillah Muhammed b. Muhammed er-Ruaynî. Mevâhibü'l-celîl li-şerḥi Muhtașarı Halîl. 6 Cilt. b.y.: Dâru'l-Fikr, 1992.

Hattabî, Ebû Süleymân Hamd (Ahmed) b. Muhammed b. İbrâhîm b. el-Büstî. Ișlâḥu ġalați'lmuḥaddisîn. thk. Hâtime ed-Dâmin. Beyrut: Müessesetü'r-Risâle, 1985.

Hattabî, Ebû Süleymân Hamd(Ahmed) b. Muhammed. Ġarîbü'l-ḥadị̂, thk. Abdülkerim İbrahim el-Garbâvî. 3 Cilt. Dımeșk: Dâru'l-Fikr, 1982.

İbn Abdülber en-Nemerî, Ebû Ömer Cemâlüddîn Yûsuf b. Abdillâh b. Muhammed. el-Kâfí fi fikhi ehli'l-Medîne. thk. Muhammed Muhammed Ehîd. 2 Cilt. Suud: Mektebetü'r-Riyâd elHadîse, 1980.

İbn Âbidîn, Muhammed Emîn b. Ömer b. Abdilazîz el-Hüseynî ed-Dımașkī. Reddü'l-muhtâr 'ale'd-Dürri'l-muhtâr. 6 Cilt. Beyrut: Dâru'l-Fikr, 1992.

İbn Cüzey, Ebü'l-Kāsım Muhammed b. Ahmed b. Muhammed el-Kelbî. el-Kavânînü'l-fiḳhiyye fí telhîși mezhhebi'l-Mâlikiyye. b.y.: y.y., ts.

İbn Düreyd, Ebû Bekr Muhammed b. el-Hasen b. Düreyd el-Ezdî el-Basrî, Cemheretü'l-lüga thk. Remzi Münir Ba'lebekkî. 3 Cilt. Beyrut: Dâru'l-İlim, 1987.

İbn Ebî Şeybe, Ebû Bekir 'Abdullah b. Muhammed b. Ebî Şeybe İbrâhîm el-Absî el-Kûfî. elMûsânnef. thk. Kemal Yusuf el-Hût. 7 Cilt. Riyad: Mektebetü'r-Rüşd, 1409.

İbn Ebî Şeybe, Ebû Bekir 'Abdullah b. Muhammed. el-Müsned, thk. Adil b. Yusuf - Ahmed b. Ferîd. 2 Cilt. Riyad: Dâru'l-Vatan, 1997. 
İbn Ebî Zeyd, Ebû Muhammed Abdullāh b. Ebî Zeyd Abdirrahmân el-Kayrevânî. en-Nevâdir ve'z-ziyâdât 'alâ mâ fi'l-Müdevvene ve ġayrihâ mine'l-ümmehât min mesẩili Mâlik ve așhâbih. thk. Muhammed Abdülaziz ed-Debbağ vd. 15 Cilt. Beyrut: Dâru'l-Garbi'lİslâmî, 1999.

İbn Ebî Zeyd, Ebû Muhammed Abdullāh. Metnü'r-Risâle. b.y.: Dâru'l-Fikr, ts.

İbn Hacer el-Askalânî, Ebü'l-Fazl Şihâbüddîn Ahmed b. Alî b. Muhammed, Fethu'l-bârî bi-şerhi Șahîhịi'l-Buhârrî. 13 cilt. Beyrut: Dâru'l-Ma'rife, 1379.

İbn Hazm, Ebû Muhammed Alî b. Ahmed b. Saîd b. Hazm el-Endelüsî el-Kurtubî. el-Muhallâ bi'lâsâr. 12 Cilt. Beyrut: Dâru'l-Fikr, ts.

İbn Hibbân, Ebû Hâtim Muhammed b. Hibbân b. Ahmed el-Büstî. el-Müsnedü'ṣ-șahîhh. thk. Şuayb el-Arnavut. 18 Cilt. Beyrut: Müessesetü'r-Risâle, 1413/1993.

İbn Huzeyme, Ebû Bekr Muhammed b. İshâk b. Huzeyme es-Sülemî en-Nîsâbûrî. es-Sahîhh. thk. Muhammed Mustafa el-A'zamî. 4 Cilt. Beyrut: el-Mektebü'l-İslâmî, ts.

İbn Hübeyre, Ebü'l-Muzaffer Avnüddîn. İhtilâfü'l-e'immeti'l-ulemâá. thk. es-Seyyid Yusuf Ahmed. 2 Cilt. Beyrut: Dâru'l-Kütübü'l-İlmiyye, 2002.

İbn Kudâme, Ebû Muhammed Muvaffakuddîn Abdullāh b. Ahmed b. Muhammed b. Kudâme. el-Muġnî. 10 Cilt. Kâhire: Mektebetü'l-Kâhire, 1968.

İbn Kudâme, Ebu'l-Ferec Şemsüddîn Abdurrahmân b. Muhammed b. Ahmed el-Makdisî. eșŞerḥu'l-kebîr. 12 Cilt. b.y.: Dâru'l-Kitâbi'l-Arabî, ts.

İbn Mâce, Ebû 'Abdillâh Muhammed b. Yezîd. Sünenü İbn Mâce, thk. Muhammed Fuad Abdülbakî. 2 Cilt. b.y.: Dâru İhyâi Kütübü’l-Arabî, ts.

İbn Müflih, Ebû Abdillâh Şemsüddîn Muhammed b. Müflih b. Muhammed el-Makdisî. Kitâbü'lFürûc. thk. Abdullah b. Abdülmuhsin et-Türkî. 11 Cilt. Beyrut: Müessesetü'r-Risâle, 2003.

İbn Nüceym, Zeynuddîn b. İbrâhîm el-Mısrî. el-Bahrü'r-rẩik. 8 Cilt. b.y.: Dâru'l-Kütübü'lİslâmiyye, ts.

İbn Rüşd el-Hafid, Ebü'l-Velîd Muhammed b. Ahmed b. Muhammed el-Kurtubî. Bidâyetü'lmüctehid ve nihâyetü'l-mukteșid. 2 Cilt. Kahire: Dâru'l-Hadîs, 2004.

İbn Teymiyye, Ebu'l-Abbâs Takıyyüddîn Ahmed b. Abdilhalim b. Abdisselam el-Harrânî. Kitâbu's- șlyam min şerhi'l'-'Umde. thk. Zâid b. Ahmed. 2 Cilt. b.y.: Dâru'l-Ensârî, 1996.

İbnü'l-Ca'd, Ebü'l-Hasen Alî b. el-Ca'd el-Cevherî. el-Müsned, thk. Âmir Ahmed Haydar. Beyrut: Müessese Nâdir, 1990.

İbnü'l-Cevzî, Ebü'l-Ferec Cemâlüddîn Abdurrahmân b. Alî b. Muhammed el-Bağdâdî. el-Keșf limüșkili'ș-Șahîhayn. thk. Ali Hüseyn el-Bevvâb. 4 cilt. Riyad: Dâru'l-Vatan, ts.

İmrânî, Ebu'l-Hüseyn Yahyâ b. Ebi'l-Hayr b. Sâlim b. Es'ad. el-Beyan fi mezhebi'l-İmam eș-Şâfi î î. thk. Kâsım Muhammed Nuri. 13 Cilt. Cidde: Dâru'l-Minhâc, 2000.

Kârâfî, Ebu'l-Abbas Șihabuddin Ahmed b. İdris, ez-Zahîre. 14 Cilt. Beyrût: Dâru'l-Ġarbi'l-İslâmî, 1994.

Kâsânî, 'Alâeddîn Ebû Bekir b. Mes'ûd, Bedâiu's-Sanâi' fî Tertîbi'ş-Şerâi'. 7 Cilt. Beyrut: Dâru'lKütübü'l-İlmiyye, 1986.

Kitab-1 Mukaddes. Erişim 31 Mayıs 2020. https://incilinfo/kitap/Levililer/23

Kudûrî, Ahmed b. Muhammed Ebu'l-Hüseyin. et-Tecrîd. 12 Cilt. Kahire: Dâru's-Selam, 2006.

Kuriel, Rika. "Yahudiler Tişa Beav'da Neden Oruç Tutarlar". Avlaremoz. Erişim 2 Nisan 2020. https://www.avlaremoz.com/2017/08/01/yahudiler-tisabeavda-neden-oructutarlar-rika-kuriel

Makrîzî, Ebû Muhammed (Ebü’l-Abbâs) Takıyyüddîn Ahmed b. Alîb. Abdilkādir b. Muhammed. İmtâ' 'u'l-esmâ' bimâ li'r-resûl mine'l-ebnẩi (enbẩi) ve'l-aḥvâl ve'l-ḥafede ve'l-metâc' thk. 
Muhammed Abdülhumeyd en-Nüseymî. 15 Cilt. Beyrut: Dâru'l-Kütübü'l-İlmiyye, 1999.

Mâlik b. Enes, Ebû Abdillâh Mâlik b. Enes b. Mâlik b. Ebî Âmir el-Asbahî el-Yemenî. el-Muvatța’ thk. Muhammed Fuad Abdülbakî. 2 Cilt. Beyrût: Daru İhyâi't-Türâsi'l-Arabî, 1985.

Maverdî, Ebu'l-Hasen Ali b. Muhammed. el-Hâvi'l-kebîr. 19 Cilt. Beyrut: Dâru'l-Kütübü'lİlmiyye, 1999.

Mevvak, Ebû Abdillâh Muhammed b. Yûsuf b. Ebi'l-Kāsım el-Mevvâk el-Abderî. et-Tâc ve'l-iklîl li-Muhtașarı Halîl. 8 Cilt. Beyrut: Dâru'l-Kütübü'l-İlmiyye, 1994.

Müslim, Ebu'l-Huseyn b. el-Haccâc en-Neysâbûrî. el-Câmi'u's-Sahîh. thk. Muhammed Fuâd Abdülbâkī. 5 Cilt. Beyrut Dâru İhyâi't-Türâsi'l-Arabî, ts.

Nesâî, Ebû 'Abdirrahmân Ahmed b. Şu'ayb. Sünenu'n-Nesâ̂i es-suggrâ. thk. Abdülfettah Ebû Gudde. 9 Cilt. Haleb: Mektebetü'l-Matbûati'l-İslâmiyye, 1986.

Nevevî, Ebû Zekeriya Muhyiddin Yahya b. Şeref. el-Mecmûc şerḥu'l-Mühezzzeb. 20 Cilt. b.y.: Dâru'l-Fikr, ts.

Nevevî. el-Minhâc șerḥu Sahih-i Müslim (Şerhu'n-Nevevî). 18 Cilt. Beyrut: Dâru İhyâ'it-Türâsi'lArabî, 1392.

Ojalvo, Denis. “İslam'da âşûrâ orucu - Yahudiler'de Hz. Süleyman Mabedi'nin ylkılışının yası orucu”. Şalom. Erişim 2 Nisan 2020. https://www.salom.com.tr/arsiv/haber-73831Islamda asure orucu yahudilerde hz suleyman mabedinin yikilisinin yasi orucu.h $\underline{\mathrm{tml}}$

Özen, Âdem. Yahudilikte İbadet. İstanbul: Marmara Üniversitesi, Sosyal Bilimler Enstitüsü, Doktora Tezi, 1999.

Râfiî', Ebu'l-Kāsım Abdülkerîm. Fetḥu'l-'azîz fị Şerḥi'l-Vecîz. 13 Cilt. b.y.: Dâru'l-Fikr, ts.

Rich, Tracey R. "Jewish Calendar". Jewfaq. Erişim 4 Nisan 2020. https://www.jewfaq.org/calendar.htm

Rûyânî, Ebu'l-Mehâsin Fahrülislâm Abdülvâhid b. İsmâîl b. Ahmed. Bahru'l-mežheb fị fürû́ mežhebi'l-İmâm eş-Şâfii î. thk. Tarık Fethi es-Seyyid. 14 Cilt. Beyrut: Dâru'l-Kütübü'lİlmiyye, 2009.

Semerkandî, Alâeddîn Ebû Bekir Muhammed b. Ahmed. Tuhfetü'l-fuḳahâ’. 3 Cilt. Beyrut: Dâru'l-Kütübü'l-İlmiyye, 1994.

Serahsî, Şemsu'l-Eimme Ebû Bekir Muhammed b. Ahmed. el-Mebsûț. 30 Cilt. Beyrut: Dâru'lMa'rife, ts.

Sevivon. Tarih Çevirme. Erişim 31 Mayıs 2020. http://www.sevivon.com/

Sıkıllî, Ebû Bekir Muhammed b. Abdullah. el-Câmi' li-mesấ'ili'l-Müdevvene. thk. Doktora Öğrencileri. 24 Cilt. b.y.: Dâru'l-Fikr, 1434/2013.

Suğdî, Ebu'l-Hasen (Hüseyn) Rüknülislâm Alî b. el-Hüseyn b. Muhammed. en-Nüteffi'l-fetâvâ, thk. Salahuddin en-Nâhî. Cilt. Amman - Beyrut: Dâru'l-Furkan - Müessesetü'r-Risâle, 1984.

Şâfi 1̂, Muhammed b. İdris. İhtilâfü'l-hadîs (el-Ümm'ün sonunda). Beyrut: Dâru'l-Ma'rife, 1990. Şâfi î, Muhammed b. İdris. el-Müsned. Beyrut: Dâru'l-Kütübü'l-İlmiyye, 1400.

Taberî, Ebû Ca'fer Muhammed b. Cerîr b. Yezîd el-Âmülî et-Taberî el-Bağdâdî. Tehzî́bü'l-âsâr ve taf̦̣̂lü'ș-sâbit 'an Resûlillâhi șallallāhu 'aleyhi ve sellem mine'l-ahbâr. thk. Mahmud Muhammed Şakir. 2 Cilt. Kahire: Matbaatü'l-Medenî, ts.

Tahâvî, Ebû Ca'fer Ahmed b. Muhammed b. Selâme. Şerḥu Müşkili'l-âsârr. thk. Şuayb el-Arnaut. 16 Cilt. Beyrut: Müessesetü Risale, 1415.

Tahâvî, Ebû Ca'fer Ahmed b. Muhammed. Şerḥu Me'âni'l-âsâr. thk. Muhammed Zührî Muhammed Seyyid Câdu'l-Hak. 5 Cilt. b.y.: Âlemü'l-Kütüb, 1994. 
Tarakçı, Muhammet. "Yahudilikte Oruç". İlsam. Erişim 02.04.2020. http://ilsam.org.tr/yahudilikte-oruc-doc-dr-muhammet-tarakci/

Tayâlisî, Ebû Dâvûd Süleymân b. Dâvûd b. el-Cârûd et-Tayâlisî. el-Müsned, thk. Muhammed b. Abdülmuhsin et-Türkî. 4 Cilt. Mısır: Dâru Hecer, 1999.

Tirmizî, Ebû 'Îsâ Muhammed b. 'Îsâ es-Sulemî. el-Câmi'u'l-kebîr (Sünen-i Tirmizî). 5 Cilt. Mısır: Mustafa Babi'l-Halebî, 1975.

$\begin{array}{llllll}\text { Tora Aftarat. } & \text { Sevivon. } & \text { Erişim } & 31 & \text { Mayis } & 2020 .\end{array}$ http://www.sevivon.com/images/stories/dokumanlar/tora kitap 5 iPad.pdf

Türk Tarih Kurumu. Tarih Çevirme Kılavuzu. Erişim 31 Mayıs 2020. https://www.ttk.gov.tr/genel/tarih-cevirme-kilavuzu.

Wensinck, A. J.. "Âşûrâ". MEB İslam Ansiklopedisi. 1/710-711. İstanbul: Milli Eğitim Basımevi, 1978.

Yavuz, Yusuf Şevki. “Âşûrâ”. Türkiye Diyanet Vakfı İslâm Ansiklopedisi. 4/24-26. İstanbul: TDV Yayınları, 1991.

Yitik, Ali İhsan. "Oruç". Türkiye Diyanet Vakfı İslâm Ansiklopedisi. 33/414-416. İstanbul: TDV Yayınları, 2007.

Zeynüddin er-Râzî, Ebû Abdullah Muhammed. Tuhfetü'l-mülûk. thk. Abdullah Nezir Ahmed. Beyrut: Dâru'l-Beşâiru'l-İslâmiyye, 1417. 